\title{
Carbon cycling and storage in world forests: biome patterns related to forest age
}

\author{
KURT S. PREGITZER and EUGÉNIE S. EUSKIRCHEN ${ }^{1}$ \\ School of Forest Resources E Environmental Science, Michigan Technological University, 1400 Townsend Ave., Houghton, \\ MI 49931, USA
}

\begin{abstract}
Forest age, which is affected by stand-replacing ecosystem disturbances (such as forest fires, harvesting, or insects), plays a distinguishing role in determining the distribution of carbon $(\mathrm{C})$ pools and fluxes in different forested ecosystems. In this synthesis, net primary productivity (NPP), net ecosystem productivity (NEP), and five pools of C (living biomass, coarse woody debris, organic soil horizons, soil, and total ecosystem) are summarized by age class for tropical, temperate, and boreal forest biomes. Estimates of variability in NPP, NEP, and C pools are provided for each biome-age class combination and the sources of variability are discussed. Aggregated biome-level estimates of NPP and NEP were higher in intermediate-aged forests (e.g., 30-120 years), while older forests (e.g., > 120 years) were generally less productive. The mean NEP in the youngest forests (0-10 years) was negative (source to the atmosphere) in both boreal and temperate biomes (-0.1 and $-1.9 \mathrm{MgCha}^{-1} \mathrm{yr}^{-1}$, respectively). Forest age is a highly significant source of variability in NEP at the biome scale; for example, mean temperate forest NEP was $-1.9,4.5,2.4,1.9$ and $1.7 \mathrm{MgC} \mathrm{ha}^{-1} \mathrm{yr}^{-1}$ across five age classes (0-10, 11-30, 31-70, 71120, 121-200 years, respectively). In general, median NPP and NEP are strongly correlated $\left(R^{2}=0.83\right)$ across all biomes and age classes, with the exception of the youngest temperate forests. Using the information gained from calculating the summary statistics for NPP and NEP, we calculated heterotrophic soil respiration $\left(R_{h}\right)$ for each age class in each biome. The mean $R_{h}$ was high in the youngest temperate age class (9.7 $\mathrm{MgCha}^{-1} \mathrm{yr}^{-1}$ ) and declined with age, implying that forest ecosystem respiration peaks when forests are young, not old. With notable exceptions, carbon pool sizes increased with age in all biomes, including soil $\mathrm{C}$. Age trends in C cycling and storage are very apparent in all three biomes and it is clear that a better understanding of how forest age and disturbance history interact will greatly improve our fundamental knowledge of the terrestrial $\mathrm{C}$ cycle.
\end{abstract}

Keywords: carbon cycling, climate change, fluxes, forest succession, global change, pools, synthesis

Received 31 July 2003; revised version received 19 February 2004 and accepted 27 April 2004

\section{Introduction}

Globally, forests store vast pools of carbon $(C)$ and even small shifts in the balance between photosynthesis and ecosystem respiration can result in a large change in the uptake or emission of carbon dioxide $\left(\mathrm{CO}_{2}\right)$ from forests to the atmosphere. Tropical, temperate, and boreal forests cover about 4.1 billion hectares of the earth's

Correspondence: Kurt S. Pregitzer, tel. + 19064872396 ,

fax + 1906487 2915, e-mail: kspregit@mtu.edu

${ }^{1}$ Present address: The Institute of Arctic Biology, University of Alaska, Fairbanks, AK 99775, USA. land surface, with forest ecosystems containing up to $80 \%$ of all aboveground terrestrial carbon (C) and $\sim 40 \%$ of all belowground terrestrial C (Dixon, 1994). Rates of both plant production and decomposition are related to latitudinal climatic gradients spanning the poles to the equator (Reich \& Bolstad, 2001). However, the net $C$ accumulation by an ecosystem over the decadal time frame depends more heavily on time since disturbance than on climate (Chapin et al., 2002). Large quantities of $\mathrm{C}$ stored in forest ecosystems for decades to centuries can be released to the atmosphere over short time steps following disturbance (Schulze et al., 2000; Page et al., 2002; Körner, 2003). Therefore, net C 
accumulation by forest ecosystems depends fundamentally on forest age (i.e. time since disturbance) and natural disturbance regimes, and land-use practices play a key role in regulating $\mathrm{C}$ cycling and storage (Houghton, 2001). The objectives of this mini-review were: (1) to synthesize $C$ pools and fluxes by age class for the boreal, temperate, and tropical forest biomes; and (2) to empirically model biome changes in pools and fluxes over time in order to better understand the overall role of disturbance in the regulation of global forest $\mathrm{C}$ cycling and storage.

Rates of forest net primary productivity (NPP; gross photosynthesis minus plant respiration) and net ecosystem productivity (NEP; gross photosynthesis minus ecosystem respiration) change over the course of stand development. Younger forests are inherently more productive than older forests (Ryan et al., 1997) and models clearly predict that successional changes in NPP influence rates of NEP through time (Thornton et al., 2002). The ideal approach to understanding agedependent trends in NEP is the simultaneous study of a carefully selected age sequence of stands, the so-called chronosequence approach. However, at the biome level, this approach is inevitably limited by the cost of establishing the many replicate chronosequences necessary to understand biome variability and by the elapsed sampling time needed to sort out disturbancerelated trends in NEP from interannual variability in NEP caused by short-term climatic variability.

Disturbance also has a large impact on ecosystem C storage. Beginning with the succession of vegetation following disturbance, forest ecosystems can accrue $\mathrm{C}$ in four major pools: vegetation, coarse woody debris (CWD), organic soil horizons, and soil. The four pools of $\mathrm{C}$ in forest ecosystems are rarely discrete, individual pools are sometimes absent (e.g. organic soil horizons, CWD), and intraecosystem transfers among pools occur on a variety of time steps as forests mature. Periods of $C$ accrual following disturbance typically range from decades to millennia and depend greatly on the growth rate (NPP) of the dominant trees and the frequency and intensity of natural or human-regulated disturbance regimes. Many trees have long average life expectancies (>100 years) and most wood and many leaves/ needles/small roots are naturally resistant to decay. Thus, pools of total ecosystem $\mathrm{C}$ in mature forests can be impressive, routinely ranging from 100-200 $\mathrm{MgCha}^{-1}$, and sometimes exceeding $500 \mathrm{MgCha}^{-1}$ (Janisch \& Harmon, 2002). Because vast quantities of $\mathrm{C}$ are stored in forests over long periods of time, the global management of forest $\mathrm{C}$ reserves has become quite controversial as nations and multinational corporations struggle to balance their internal economic and social agendas against the realization that combus- tion of fossil fuels and land-use practices are altering the Earth's climate system (Schulze et al., 2002).

Our underlying hypothesis is that disturbance (time) trends are so fundamental in regulating NPP, NEP, and C storage that they will be apparent at the biome level in spite of the tremendous variability in $\mathrm{C}$ pools and fluxes at this scale. In other words, the modeled age trends apparent across an individual chronosequence (Thornton et al., 2002) should be apparent at the biome scale where sufficient data are available to model biome age trends. We also discuss the pitfalls of our synthesis and emphasize statistical variability in $C$ pools and fluxes. Most biome-level reviews of forest $\mathrm{C}$ cycling and storage produce estimates averaged across age classes (but see Schulze et al., 1999) and many lack statistical estimates of variability and information on one or more storage pools, typically CWD and soil C; thus, it has been difficult to appreciate the overall effect of disturbance (age) on biome pools and fluxes of C. By synthesizing global information on forest NPP and $\mathrm{NEP}$, we were able to calculate age trends in heterotrophic soil respiration $\left(R_{\mathrm{h}}\right)$ for each biome.

\section{Methods}

\section{Database compilation}

Our database includes information pertaining to carbon pools (C in the total ecosystem, living biomass, CWD, organic soil horizons, and soil) and carbon fluxes (NPP and NEP) for the boreal, temperate, and tropical biomes (Appendix A). It includes deciduous, coniferous, and evergreen species encompassing a broad range of stand ages and geographic locations. We deliberately included both managed and unmanaged forests as well as studies that incorporated varying methodologies in order to acquire the broadest possible array of data. The entire database is comprised of approximately 1200 entries, taken from 120 references, 15 of which are chronosequence studies. The primary decisive factor for including data was availability in the peerreviewed, open literature, and sufficient documentation of the field measurements as well as the age and location of the stand under consideration. Review papers that followed these same guidelines are also included (e.g., Harmon et al., 1986; Gower et al., 1994; Clark et al., 2001; Gower et al., 2001; Law et al., 2002). Those papers that estimated the above parameters based primarily on models were excluded. None of the data reported come from unpublished sources. The data were summarized as reported and no assumptions or corrections were made to the original data. If more than one method was applied to estimate a given pool or flux in a particular study, we used the estimate(s) 
that the authors deemed more accurate. We converted all the data to standard units, $\mathrm{MgCha}^{-1}$ (pools) or $\mathrm{MgCha}{ }^{-1} \mathrm{yr}^{-1}$ (fluxes), and when necessary, applied a conversion factor of 0.5 to estimate the amount of carbon from a given oven-dry biomass.

The soil $\mathrm{C}$ database reports measurements made to different cumulative depths, including both organic and mineral soils. No attempt was made to correct soil $\mathrm{C}$ for the depth of measurement, although we recognize that total soil C increases with depth (Jobbagy \& Jackson, 2000). However, we do report the depth(s) to which soil samples were collected in Appendix A. We chose to synthesize organic layer soil horizon data separately from the underlying soil horizons because there is a rich literature on $\mathrm{C}$ content in the organic soil horizons ('forest floor'), and these measurements are often independent of mineral soil horizon $C$ measurements (i.e. the 'forest floor' $\mathrm{C}$ content is often reported independently without subsequent reports of the $\mathrm{C}$ content of the underlying soil horizons). We tabulated organic layer soil horizon pool sizes when these layers were explicitly identified in the literature and we made no attempt to reinterpret whether or not the organic soil horizons were properly identified according to standard soil survey procedures, which are explained in Soil Taxonomy (Soil Survey Staff, 1975).

The total ecosystem, living biomass, and NPP data were restricted to those studies that included actual measurement of both above- and belowground components, and only NPP data reported on a per unit area basis were utilized. Restricting data in this way should minimize the effects of changes in stand management and self-thinning on estimates of NPP. The data pertaining to NEP primarily include values obtained via micrometerological techniques (e.g., eddy covariance). Three studies in the database used biometric methods to calculate NEP, and two of these were chronosequence studies. We attempted to perform a thorough review of the literature, but understand that valuable references may have been unintentionally omitted. We also recognize that our results depend fundamentally on the number of observations and the literature included in the database.

\section{Statistical analyses}

The deciduous, coniferous, and evergreen species for each biome were pooled to attain sufficient data to examine trends over time. The data were then divided into five age classes to (1) represent key developmental periods over the course of forest succession, and (2) ensure that each age class would generally contain enough data to perform meaningful statistical analyses. As such, the age classes for the boreal forest were slightly different from those for the temperate and tropical forests to take into account the slower growing nature of the boreal trees. For example, those data in the youngest age class for boreal forests range from 0 to 30 years, while those in the temperate and tropical forest range from 0 to 10 years.

For all the carbon pools and fluxes, summary statistics by age class and for all age classes combined were computed and Duncan's multiple range test was performed using PROC ANOVA of the SAS software (SAS Institute, 1990,version 6.0) to check for significant differences in the mean values of NEP and NPP across age classes for a given biome. Empirical nonlinear functions were then fit to the median values of the carbon flux and carbon pool data by age groups (excluding those with two or fewer observations) using the iterative Gauss-Newton method with specified ranges of starting values in PROC NLIN of the SAS software (SAS Institute, version 6.0). In each case, several different models were tested and compared for fit using F-tests (Rice, 1995). Plots of the fitted values vs. the residuals were visually examined for heteroscedacity to aid in validating the models. The functions were deliberately not fitted to the mean values of the carbon pool and flux data because of outliers in many of the age classes. Details of the precise models implemented are presented in Table 1.

When we examined the relationship between NEP and NPP, we removed all biometric estimates of NEP from the database in order to create NPP and NEP data sets that were independent in terms of how measurements were taken. Consequently, for this analysis, all NPP data were developed from biometric ground measurements through time, while the subset of NEP data all comes from published eddy flux measurements.

Measurement of heterotrophic soil respiration $\left(R_{\mathrm{h}}\right)$ at the ecosystem level has been problematic for many years (Hanson et al., 2000). Nevertheless, because we developed independent average measurements of NPP and NEP for different age classes at the biome level, we were able to calculate average $R_{\mathrm{h}}$ for each age class in each biome as

$$
R h_{\text {age, biome }}=\mathrm{NPP}_{\text {age, biome }}-\mathrm{NEP}_{\text {age, biome }} .
$$

\section{Results}

Carbon fluxes

NPP. The mean boreal forest NPP across all age classes was $2.8( \pm 1.6) \mathrm{MgC} \mathrm{ha}^{-1} \mathrm{yr}^{-1}$ and increased from 7.1 $( \pm 3.5)$ in temperate forests to $8.3( \pm 5.2)$ in tropical forests. NPP peaked at intermediate ages in boreal and 
Table 1 Parameters, sum of squared errors, and $P$-values from curves fitted to the medians of components of the forest carbon budgets across five age classes

\begin{tabular}{|c|c|c|c|c|c|c|c|}
\hline $\mathrm{C}$ budget component & Biome & Function* & $a$ & $b$ & $c$ & $\mathrm{SSE}^{\dagger}$ & $P$-value \\
\hline \multirow[t]{4}{*}{ Living biomass } & Boreal $^{\ddagger}$ & Sigm & 15134 & 9306 & - & 8.8 & $<0.05$ \\
\hline & Temperate & Hyp & 206.0 & 131.0 & - & 108.3 & $<0.05$ \\
\hline & Tropical & Pow & 11.69 & 0.39 & - & 88.0 & $<0.05$ \\
\hline & Boreal $^{\ddagger}$ & Pow & 4.28 & 0.089 & - & 0.2 & $<0.05$ \\
\hline \multirow[t]{2}{*}{ CWD } & Temperate & Mix & 161.5 & 0.094 & 2.55 & 98.3 & 0.08 \\
\hline & Tropical & Pow & 102.3 & -0.628 & - & 40.4 & $<0.05$ \\
\hline \multirow[t]{4}{*}{ Organic soil horizons } & Boreal & $\log n$ & 21.91 & 0.80 & 177.4 & 25.7 & $<0.05$ \\
\hline & Temperate & Sigm & 8856 & 3170 & - & 92.9 & $<0.05$ \\
\hline & Tropical & $\log n$ & 28.45 & 0.21 & 183.9 & 69.2 & 0.13 \\
\hline & Boreal $^{\ddagger}$ & Mix & -219.4 & 0.201 & 109.2 & 427.5 & 0.20 \\
\hline \multirow[t]{3}{*}{ Soil } & Temperate & Mix & 178.6 & 0.092 & 52.29 & 446.7 & 0.30 \\
\hline & Tropical $^{\ddagger}$ & Hyp & 111.0 & 11.05 & - & 554.6 & $<0.05$ \\
\hline & Boreal & Hyp & 119.2 & 8.1 & - & 1677.9 & $<0.05$ \\
\hline \multirow[t]{2}{*}{ Total ecosystem } & Temperate & Sigm & 427786 & 212025 & - & 14280 & $<0.05$ \\
\hline & Tropical & Pow & 53.7 & 0.26 & - & 446.2 & $<0.05$ \\
\hline \multirow[t]{3}{*}{ NPP } & Boreal & $\log n$ & 2.8919 & 0.7163 & 66.4462 & 0.2 & $<0.05$ \\
\hline & Temperate & Logn & 8.0826 & 0.9850 & 27.9749 & 1.4 & $<0.05$ \\
\hline & Tropical $^{\S}$ & - & - & - & - & - & - \\
\hline \multirow[t]{3}{*}{ NEP } & Boreal & $\log n$ & 2.74376 & 0.1100 & 47.6843 & 0.1 & 0.13 \\
\hline & Temperate & Logn & 6.7021 & 0.1617 & 38.4328 & 7.5 & 0.20 \\
\hline & Tropical $^{\S}$ & & - & - & - & - & - \\
\hline NEP vs. NPP & All biomes & Linear & -0.90 & 0.57 & - & 0.70 & $<0.001$ \\
\hline
\end{tabular}

*Explanation of functions used: A. Lognormal, ' $\operatorname{logn}$ ', $Y=a \times \exp \left\{-0.5[\ln (A / c) / b]^{2}\right\} ;$ B. Sigmoidal, 'sigm', $Y=(a \times A) /\left(A^{2}+b\right) ; \mathrm{C}$. Mixed, 'mixed', $Y=(a / A)+(b \times \mathrm{A})+c$; D. Power, 'pow', $Y=a \times A^{b}$; E. Hyperbolic, 'hyp', $Y=(a \times A) /(b+A)$, where $a, b$, and $c$ are estimated parameters, $A$ is the age of the ecosystem, and $Y$ is the predicted pool or flux.

${ }^{\dagger} \mathrm{SSE}$, sum of squared errors. $R^{2}$ for all models was 0.9 or above, where $R^{2}$ for the nonlinear models is defined as (1-SSE/CSS), where SSE is the variance of the full model, and CSS (corrected sum of squares) is the variance of the mean model.

${ }^{\ddagger}$ These models do not include data from either age class ' $D$ ' or ' $E$ ' because of the low number of observations.

$\S_{\mathrm{NPP}}$ and NEP for the tropical forest were not modeled because of lack of data for most age classes.

'Constants were subtracted and added to the lognormal function when fitting this model to eliminate the constraints imposed on the tails of the lognormal curve. More precise methods of parameterizing the NEP distribution curve can be found in Euskirchen et al. (2002). CWD, coarse woody debris; NPP, net primary productivity; NEP, net ecosystem productivity.

temperate forests, but there were insufficient data to determine whether this trend also occurs in tropical forests (Fig. 1). In the boreal forest, peak NPP occurred in the 71-120 years age class, while NPP peaked in the 11-30 years age class in temperate forests. Across all age classes and biomes, NPP was variable (Fig. 1), with coefficients of variation ranging from a low of $19 \%$ (boreal forests 120-200 years old) to a high of $117 \%$ (boreal forests 0-30 years old).

NEP. The mean NEP across all age classes was 0.3 $( \pm 1.1) \mathrm{MgC} \mathrm{ha}^{-1} \mathrm{yr}^{-1}$ in boreal forests, $1.7( \pm 3.2)$ in temperate forests, and $3.6( \pm 2.9)$ in tropical forests. NEP also peaked at intermediate ages in boreal and temperate forests and the pattern of NEP through stand development mirrored that for NPP (Fig. 1). The youngest age class in boreal forests exhibited mean rates of NEP that were negative (source to the atmosphere; $-0.1 \mathrm{MgC} \mathrm{ha}^{-1} \mathrm{yr}^{-1}$ ). The $120-200$ years age class in boreal forests also had a negative rate of NEP $\left(-0.9 \mathrm{MgC} \mathrm{ha}^{-1} \mathrm{yr}^{-1}\right)$, primarily because of a 150year-old spruce stand in European Russia, which acted as a strong carbon source for 3 years in a row (Milyukova et al., 2002). There were insufficient data from tropical forests to study the trends in NEP through time and only one age class is reported (Fig. 1). In general, rates of NEP across all age classes and biomes were much more variable than rates of NPP (Fig. 1). Coefficients of variation ranged from an overall low of $61 \%$ in temperate forests $11-30$ years old to an overall high of $-1087 \%$ in temperate forests $0-11$ years old. Potential explanations for this variability in NEP are discussed below. Regardless of variability, two important points are clear (Fig. 1): (1) time trends in 


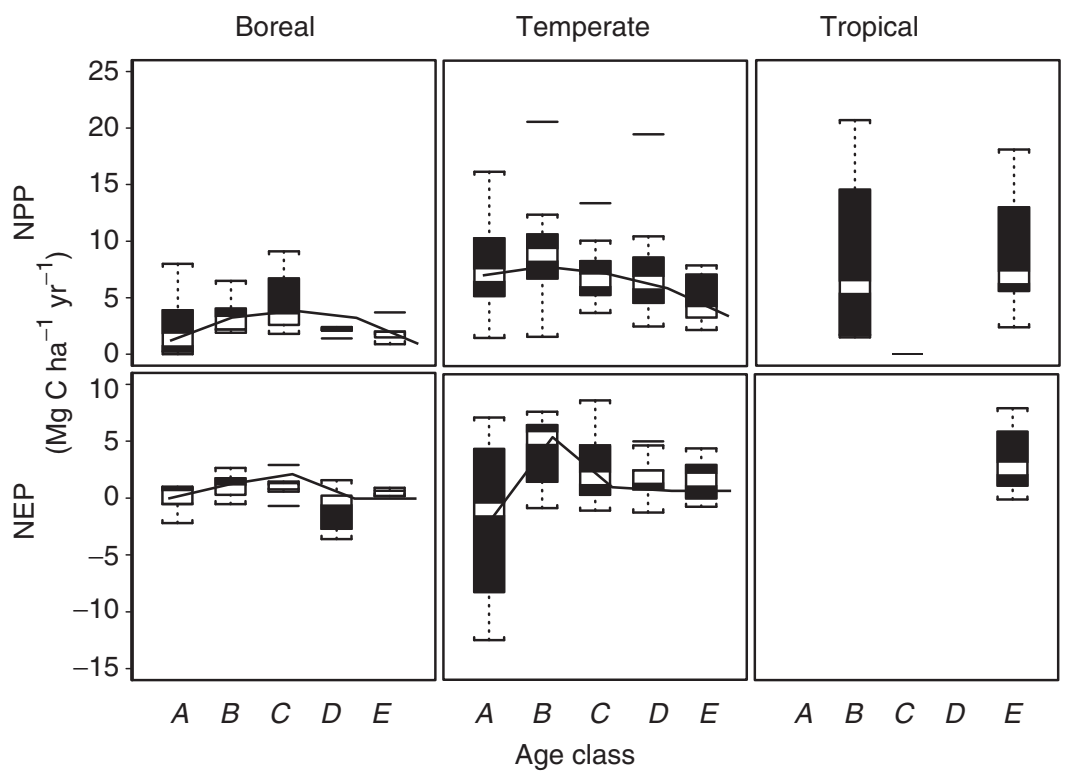

Fig. 1 Variation in net primary productivity (NPP) and net ecosystem productivity (NEP) $\left(\mathrm{MgCha}^{-1} \mathrm{yr}^{-1}\right)$ over time across boreal, temperate, and tropical forest biomes. Lines are fitted through the medians (horizontal white lines in the interior of the boxplots) of each age class with associated functions and parameter estimates detailed in Table 1. The height of the boxes is equal to the interquartile distance with the dotted lines from the top and bottom extending to the extreme values of the data, or a distance of $1.5 \times$ interquartile distance, whichever is less. The single horizontal lines outside the boxes are the outliers. Age classes, in years, are as follows: for the boreal biome, $A=0-30 ; B=31-70, C=71-120 ; D=121-200 ; E=>200$, and for the temperate and tropical biomes, $A=0-10 ; B=11-30$; $C=31-70 ; D=71-120 ; E=121-200$.

boreal and temperate NEP follow those of NPP, with a peak at intermediate ages; and (2) boreal forests, regardless of age, hover about zero NEP. More studies are needed in tropical forests, especially young and middle-aged tropical forests, to determine whether forests in all three biomes follow the same general developmental trends through time.

Relationship between NPP and NEP. In general, median NPP and NEP were strongly correlated across all age classes and biomes, with one notable exception (Fig. 2). The highly significant linear relationship between NPP and NEP depicted in Fig. 2 depends on the omission of one outlier, the median of NPP plotted against the median of NEP for the youngest age class of the temperate forests. In this case, NPP is around $7 \mathrm{MgCha}^{-1} \mathrm{yr}^{-1}$, but NEP is negative $\left(-1 \mathrm{MgCha}^{-1} \mathrm{yr}^{-1}\right)$ due in large part to high rates of woody debris decomposition following harvest in Florida slash pine plantations (Gholz \& Fisher, 1982; Thornton et al., 2002). This observation agrees with the overall high variability in NEP for the youngest age class of the temperate forests (Fig. 1), which we believe is because of the wide range of management activities associated with timber harvest and site preparation, as discussed below.
Heterotrophic soil respiration $\left(\mathrm{R}_{h}\right)$. Average rates of $R_{\mathrm{h}}$ (Eqn (1)) range from 1.5 to $3.5 \mathrm{MgCha}^{-1} \mathrm{yr}^{-1}$ in boreal forests (Fig. 3). In temperate forests, rates decline from $9.7 \mathrm{MgC} \mathrm{ha}^{-1} \mathrm{yr}^{-1}$ in the youngest age class to $2.8 \mathrm{MgC} \mathrm{ha}^{-1} \mathrm{yr}^{-1}$ in the oldest forests (Fig. 3). Tropical forests $>120$ years old exhibit rates of $R_{\mathrm{h}}$ that average $4.6 \mathrm{MgCha}^{-1} \mathrm{yr}^{-1}$ (Fig. 3), an amount that is $164 \%$ greater than the same age class of temperate forests.

\section{Carbon pool sizes}

Living biomass. Living biomass $\mathrm{C}$ increased with age across boreal, temperate, and tropical forests, as would be expected (Fig. 4). High variability in temperate biomass $C$ in the oldest age class (Fig. 4) results from the inclusion of several studies from the Pacific Northwestern Region of North America. Living forest biomass $C$ reaches its peak globally in this region and many old-growth stands are dominated by massive trees reaching ages exceeding 400 years (Harmon et al., 1990). With the exception of this age class (temperate old), it is interesting how predictable changes in living tree biomass are across the age class - biome categories (Table 1, Fig. 4). There were no studies in the database for tropical forests 71-120 years old. 


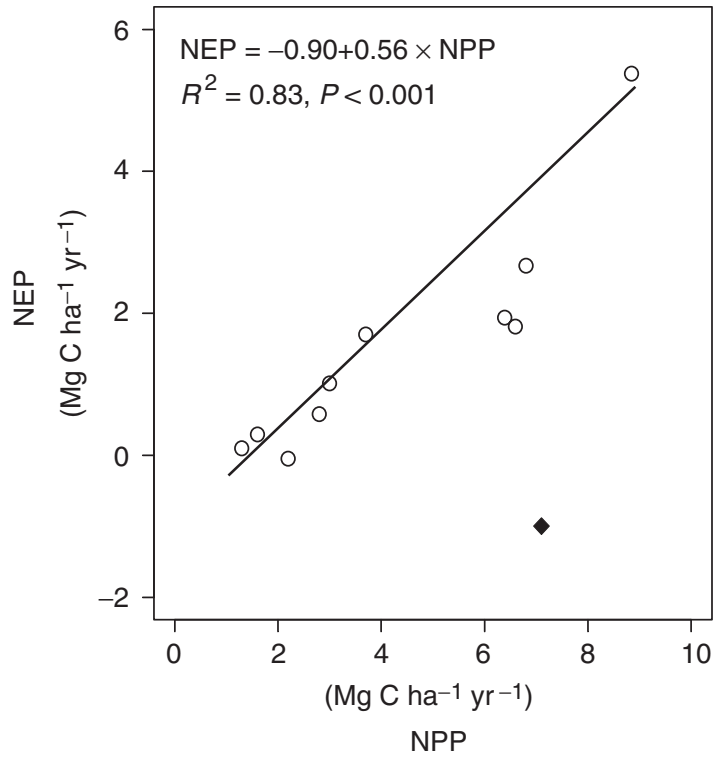

Fig. 2 Relationship between the median values of net ecosystem productivity (NEP) and net primary productivity (NPP) $\left(\mathrm{MgCha}^{-1} \mathrm{yr}^{-1}\right)$, with the line representing the fitted linear least-squares relationship. The solid black point represents the young age class for the temperate forests, and was not included in the model. The NEP data represent only those data obtained via micrometeorological techniques (e.g., as measured by the eddy covariance method) so that the methods of collecting the NPP and NEP data are independent. Detailed parameter estimates are given in Table 1 . Age classes, in years, are as follows: for the boreal biome, $A=0-30 ; B=31-70, C=71-120$; $D=121-200 ; E=>200$, and for the temperate and tropical biomes, $A=0-10 ; B=11-30 ; C=31-70 ; D=71-120 ; E=121-200$.

Organic soil horizons. Mean and median organic soil horizon pool sizes increased with age in boreal, temperate and tropical forests, reaching a peak in the 71 or older age classes (Fig. 4). The standard deviations within an age class (data not shown) and the box plots in Fig. 4 clearly demonstrate that organic soil horizon pool sizes are highly variable across all three biomes.

Soil. The overall mean $\mathrm{C}$ content of soil, excluding the surface organic soil horizons ('forest floor'), across all age classes, was $151.6( \pm 175.2), 82.3( \pm 39.5)$, and 84.2 $( \pm 49.6) \mathrm{MgCha}^{-1}$ for the boreal, temperate, and tropical forests, respectively. The soil $\mathrm{C}$ pools were highly variable, particularly within the boreal biome. Across all biomes, there was an overall trend for soil pool sizes to increase through time (Fig. 4).

CWD. The pool size of CWD across all age classes was relatively small in boreal forests (mean $7.9 \pm$ $7.5 \mathrm{Mg}\left(\mathrm{ha}^{-1}\right.$ ) and accounted for an average of about $5 \%$ of the total ecosystem $\mathrm{C}$. The stage of stand develop-

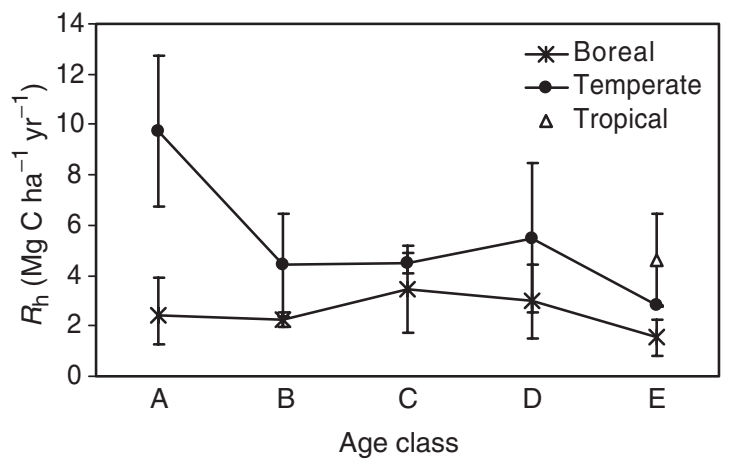

Fig. $3 R_{\mathrm{h}}\left(\mathrm{MgC} \mathrm{ha}^{-1} \mathrm{yr}^{-1}\right)$ calculated from average net primary productivity (NPP) subtracted from average net ecosystem productivity (NEP) across all age classes. The error bars are calculated as $R_{\mathrm{h}}=(\mathrm{NPP} \pm \sigma \mathrm{NPP})-(\mathrm{NEP} \pm \sigma \mathrm{NEP})$. NEP data were unavailable for age classes $A-D$ in the tropical biome. Age classes, in years, are as follows: for the boreal biome, $A=0-30$; $B=31-70, \quad C=71-120 ; \quad D=121-200 ; E=>200$, and for the temperate and tropical biomes, $A=0-10 ; B=11-30 ; C=31-70$; $D=71-120 ; E=>121$.

ment appears, on the average, to have little overall influence on the pool size of CWD in boreal forests (Fig. 4). The mean pool size of CWD averaged across all temperate age classes was $42.0( \pm 45.8) \mathrm{MgC} \mathrm{ha}^{-1}$, or about $18 \%$ of the total ecosystem C. Pools of CWD were much more variable in temperate forests, especially in the youngest and oldest age classes (Fig. 4). In the tropics, the mean CWD pool size across all age classes was $17.5( \pm 15.9) \mathrm{MgCha}^{-1}$, or roughly $10 \%$ of the total ecosystem $\mathrm{C}$. The youngest age class was the most variable pool of CWD in the tropics (Fig. 4).

Total ecosystem carbon. Total ecosystem $\mathrm{C}$ increased with age in the boreal forest (Fig. 4) and C peaked in the 120200 years age class, following the same pattern described for living biomass. The mean total ecosystem $C$ across all boreal age classes was 143 ( \pm 93) $\mathrm{MgC} \mathrm{ha}^{-1}$. Older boreal age classes were more variable than younger age classes (Fig. 4). Total ecosystem $\mathrm{C}$ also increased with age in temperate forests (Fig. 4); the mean total ecosystem $\mathrm{C}$ across all temperate age classes was $\left.239( \pm 101) \mathrm{MgCha}^{-1}\right)$. Variability in total temperate ecosystem $\mathrm{C}$ was relatively low through the first four age classes, but was very high in the oldest age class (Fig. 4), once again presumably because of the inclusion of several studies from the Pacific Northwestern Region of North America, where pools of living biomass and CWD are high in old-growth forests (Janisch \& Harmon, 2002). The mean tropical total ecosystem $\mathrm{C}$ was 174 $( \pm 54) \mathrm{MgCha}^{-1}$ and total ecosystem $\mathrm{C}$ increased 


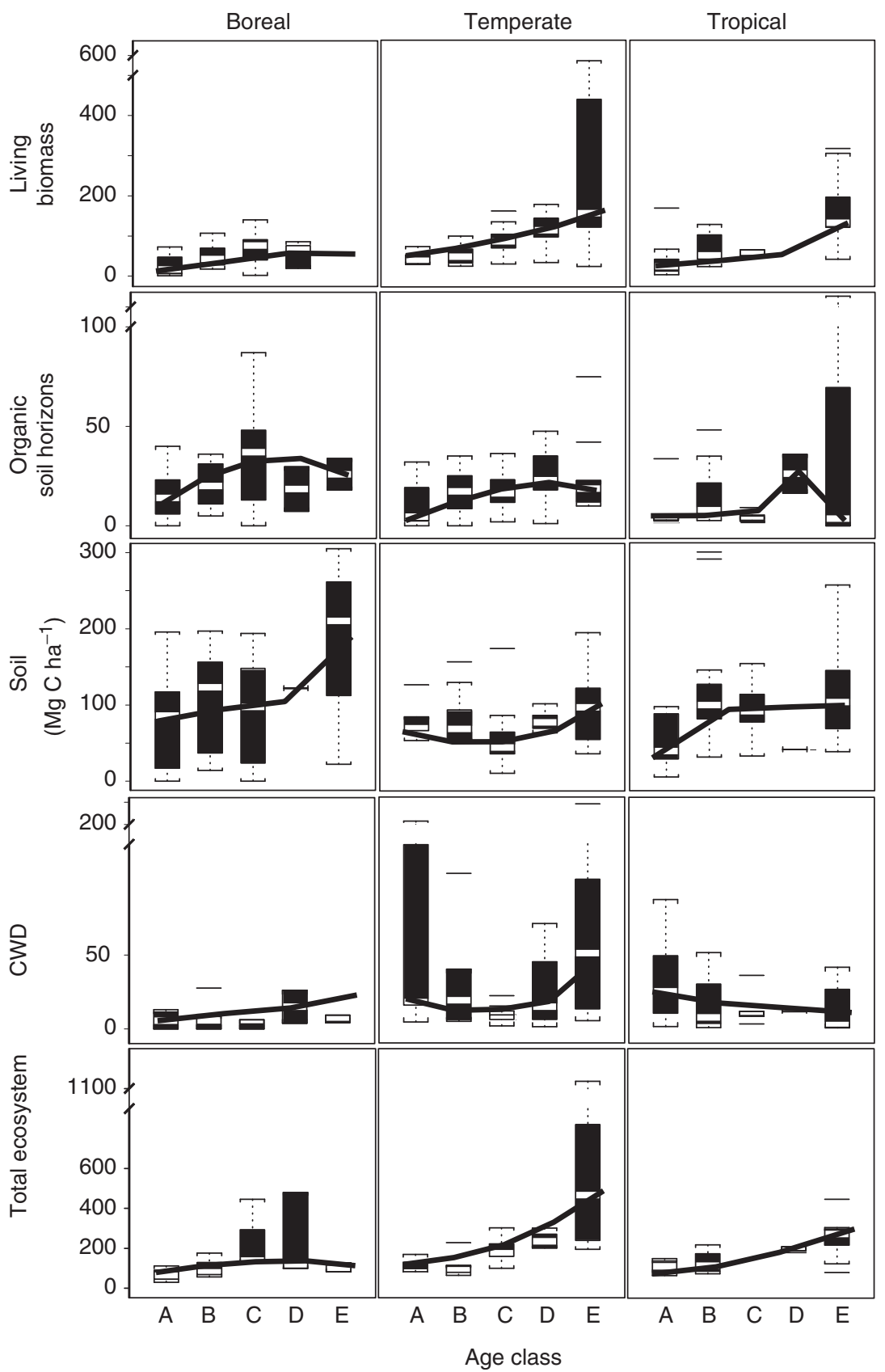

Fig. 4 Variation in the pools ( $\mathrm{MgC} \mathrm{ha}^{-1}$ ) of living biomass, organic soil horizons, soil, coarse woody debris (CWD), and total ecosystem carbon over time across boreal, temperate, and tropical forest biomes. Lines are fitted through the medians (horizontal lines in the interior of the boxplots) of each age class with associated functions and parameter estimates detailed in Table 1. The height of the boxes is equal to the interquartile distance with the dotted lines from the top and bottom extending to the extreme values of the data, or a distance of $1.5 \times$ interquartile distance, whichever is less. The single horizontal lines outside the boxes are the outliers. Age classes, in years, are as follows: for the boreal biome, $A=0-30 ; B=31-70, C=71-120 ; D=121-200 ; E=>200$, and for the temperate and tropical biomes, $A=0-10 ; B=11-30 ; C=31-70 ; D=71-120 ; E=121-200$.

with age class (Fig. 4). Variability in the total ecosystem $\mathrm{C}$ was relatively low in tropical forests compared with temperate and boreal forests, especially when comparing the older age classes among the biomes (Fig. 4).

\section{Discussion}

\section{Critical appraisal of the data and its limitations}

There are numerous problems associated with binning data collected by a multitude of investigators using 
varying methodologies. One clear example is the data on soil organic horizons and soil. The soil organic horizons ('forest floor') are technically a part of the soil profile, and the 'O layer' is typically subdivided into the fibric (Oi), hemic (Oe), and/or sapric (Oa) layers in the USA (Soil Survey Staff, 1975). However, the 'forest floor' has been variously defined and the distinction between the forest floor and soil is artificial. Some of the variability in $\mathrm{C}$ pools in the organic soil horizons and soil that we report is undoubtedly related to how these layers are defined and reported in the literature. The distinction in the literature between the forest floor and soil is particularly problematic for imperfectly and poorly drained soils. Furthermore, the soil $\mathrm{C}$ database we compiled reports measurements made to different cumulative depths, including both organic and mineral soils. Obviously, some of the variability in the soil organic horizon and soil C stocks we report is simply because of the way in which we summarized the data and the different methods of sampling and reporting soil $\mathrm{C}$ in the literature.

The three biomes also contain different proportions of managed and unmanaged forests. In general, the temperate forests are more intensively managed than the tropical and boreal biomes at this time in history. Controlling species composition, genetic improvement of growing stock, fertilization, weed control, and irrigation are all examples of cultural practices applied ever more frequently in forest plantation culture. Intensively cultured plantation forests with high rates of NPP can accumulate $\mathrm{C}$ stocks in living biomass in just a few years, which are typical of mature naturally regenerated forests in the region (Madeira et al., 2002).

Forests in different regions within a biome are also influenced by inherently different rates of NPP related to many site factors such as climate, soil, and drainage. The life-history attributes of different native and exotic species can also play an important role in regulating C storage in living biomass (Jackson et al., 2000). Binning data across different sites by species combinations add to the inherent variability within the database and should mask age-related patterns in C cycling and storage.

Can we meaningfully interpret the influence of disturbance (age) on biome-scale C cycling and storage using such a wide array of information? Our synthesis and interpretation certainly have limitations; nonetheless, the patterns related to forest age discussed below transcend all the variability inherent in our database. The fact that age-related patterns in C cycling and storage are very apparent, in spite of the caveats we discuss above, suggest that we need to pay more attention to the role of disturbance in regulating $\mathrm{C}$ cycling and storage. For example, many of the current sites in the networks measuring NEP tend to be located in undisturbed, mature, 'representative' forests, but, as we discuss below, these sites, on the average, have low rates of NEP compared with younger stands. Obviously, as new data from existing studies become available we will be able to refine our understanding of how disturbance regulates $\mathrm{C}$ cycling and storage in forests located along edaphic and climatic gradients.

\section{NPP}

Our results demonstrate that the pattern of decline in forest productivity with age, apparent at the stand level (Ryan et al., 1997), can be seen in average rates of boreal and temperate NPP aggregated to the biome level (Fig. 1). Because we only used studies reporting both aboveand belowground NPP data expressed on a per unit land area basis, these results should be robust in the face of different stand densities and management histories. There is some debate about how much more productive young forests are compared with older forests, centering on management history, stand density, and assumptions made in models of forest growth (Carey et al., 2001; Knohl et al., in press). Our analysis of NPP makes no assumptions whatsoever and the data cut across all types of temperate and boreal forests, including forests that are even-aged and those that are of mixed ages and species composition from virtually every habitat ever reported in the literature. Nonetheless, the pattern of decline in NPP with age is clear (Fig. 1), although the reasons for this are not fully apparent (Ryan et al., 1997).

\section{NEP}

Variability in NEP within boreal, temperate, and tropical forests is high (Fig. 1). Some of this variability is driven by the same set of factors that drive changes in photosynthesis (Gu et al., 2003) and plant respiration (Clark et al., 2003). However, much of the variability in NEP is related to changes in the factors that drive $R_{\mathrm{h}}$ (Goulden et al., 1998; Valentini et al., 2000). Heterotrophic soil respiration $\left(R_{\mathrm{h}}\right)$ is regulated by the enzymatic and metabolic activity of the soil foodweb. The factors limiting $R_{\mathrm{h}}$ are not the same as those that limit photosynthesis. The chemical composition of plant detritus is important in regulating the rate of soil organic matter decomposition (Cadish \& Giller, 1997), as are soil temperature, soil moisture (including drainage class), and soil oxygen content.

Different soil environmental conditions, for example, the depth of thaw in permanently frozen boreal soils, can also change from year to year, making labile soil $\mathrm{C}$ available for decomposition in 1 year and not the next 
(Goulden et al., 1998). Thus, NPP and NEP are not always coupled in time. However, in general, median NEP was strongly correlated to median NPP across all age classes and biomes (Fig. 2). This makes sense, because soil microbial metabolism is normally tightly linked to the availability of labile substrates coming primarily from leaf and fine root litter and root exudates (Zak \& Pregitzer, 1998; Högberg et al., 2001). Ecosystem NEP can only be decoupled from NPP if the conditions regulating the availability of labile substrates or the environmental conditions limiting microbial enzymatic and metabolic activity somehow change. Our results suggest that, on the average, this occurs most routinely just following disturbance, when biome $R_{\mathrm{h}}$ is high and median and mean NEP are negative (source to the atmosphere; Fig. 3).

During the intermediate stages of stand development when NPP and NEP are highest (Fig. 1), variability in NEP is lower. Although it is not possible to separate these sources of variation explicitly given the information we currently have available, we can infer that the $390 \% \mathrm{cv}$ for the young age class is due primarily to the time since disturbance, when decomposition rates are high at first and depend on the intensity and type of disturbance (Chapin et al., 2002; Thornton et al., 2002). As forests reorganize their internal biogeochemical cycles and mature (intermediate age classes), NPP and NEP are high (Fig. 1) and appear to be primarily responding to interannual climatic variation, favoring either increased photosynthesis or decreased respiration (Myneni et al., 1997; Schimel et al., 2000). On the whole, the greatest amount of variability in NEP over the course of succession appears to be attributable to time since disturbance rather than interannual variations in climate or long-term environmental trends (Chapin et al., 2002), underscoring the importance of land-use history and forest management practices in the regulation of global pools and fluxes of forest $C$.

\section{Heterotrophic soil respiration $\left(\mathrm{R}_{h}\right)$}

Disturbance-induced increases in $R_{\mathrm{h}}$ early in succession appear to be very important in temperate forests, with mean rates of $R_{\mathrm{h}}$ at $9.7 \mathrm{MgC} \mathrm{ha}^{-1} \mathrm{yr}^{-1}$ in the 0 -10-year age class (Fig. 3). Obviously, any forest management practice that reduces the pulse of $R_{\mathrm{h}}$ associated with disturbance will accelerate the development of positive NEP. We expect that tropical forests will exhibit a pattern of $R_{\mathrm{h}}$ through time similar to the pattern exhibited by temperate forests in Fig. 3, with a peak early in succession and a decline through time, but the data are insufficient to test this hypothesis at this time. Because NPP (Fig. 1) and $R_{\mathrm{h}}$ (Fig. 3) decline as forests age, total ecosystem respiration must also decline during the later stages of forest succession. If soil respiration is dominated by plant respiration and microbial respiration of labile C substrates (Zak \& Pregitzer, 1998; Högberg et al., 2001), there is no reason to expect the oldest forests to exhibit the highest rates of ecosystem respiration as Odum (1969) originally hypothesized.

\section{Carbon pool sizes}

Living biomass. Living biomass $\mathrm{C}$ increased through time, peaking in the 71-120-year age class in boreal forests, but increasing steadily with age in temperate and tropical forests (Fig. 4). The older age classes contained two to 10 times as much living biomass $\mathrm{C}$ as the youngest age class. Boreal biomass $C$ peaks at an earlier age compared with the temperate or tropical biomes, presumably because catastrophic wildfire is the predominant form of disturbance across the boreal landscape (Kasischke \& Stocks, 2000), and because many poorly drained forests lose tree cover as moss biomass increases and soil temperature declines during the advanced stages of forest succession (Van Cleve \& Viereck, 1981).

Organic soil horizons. In many forest soils, surface layers accumulate, which are rich in organic matter composed primarily of plant litter in various stages of decay. These 'forest floor' layers are believed to be highly active in forest $\mathrm{C}$ cycling, especially in response to disturbance (Covington, 1981; Yanai et al., 2003). At the biome level, it is clear that average forest floor $\mathrm{C}$ contents either remain relatively constant or increase with age, and median forest floor $C$ reached a peak in all three biomes after about 70 years of stand development (Fig. 4). Yanai et al. (2003) review the reasons why the common assumption of increased forest floor decay following disturbance may not be valid in many instances.

Soil carbon. Carbon is stored in soil when it is unavailable for use by microorganisms. The formation of mineral soil $\mathrm{C}$ with a relatively long residence time (stable or passive soil C) is thought to be primarily controlled by three mechanisms: (1) chemical stabilization, (2) physical protection, and (3) biochemical stabilization (Six et al., 2002). All three of the soil C stabilization mechanisms co-vary across the landscape with changes in soil parent material and vegetation type. This is one reason why soil $\mathrm{C}$ pools are so variable within a given biome (Fig. 4). Other factors controlling variability in soil C are soil drainage, soil temperature, and variability in $\mathrm{C}$ inputs through time. Poorly drained and cold soils accrue significant $\mathrm{C}$ 
contents because lack of oxygen and low temperatures inhibit rates of decomposition. These two phenomena are much more frequent in boreal forests where pools of soil $\mathrm{C}$ are both high and highly variable because of the greater frequency of cold and saturated soils (Fig. 4; Gower et al., 1997; Harden et al., 1997; Chapin et al., 2002). Labile soil $C$ also cycles back to the atmosphere on longer time steps in boreal forests compared with temperate and tropical forests (Trumbore, 2000), which means that a greater proportion of the total $\mathrm{C}$ pool in wet and cold boreal soils has not been stabilized by one of the three mechanisms discussed above. This soil $C$ could be susceptible to further decomposition if the conditions that currently limit microbial respiration change. Interestingly, median soil $\mathrm{C}$ at the biome level increased with time (cumulative inputs) in all three biomes (Fig. 4), a finding contrary to the notion that soil C contents often vary little through time (Johnson \& Curtis, 2001).

CWD. The factors regulating the decomposition of CWD are essentially the same as those that regulate $R_{\mathrm{h}}$ in the soil: detrital substrate quality, temperature, moisture, and oxygen content (Wang et al., 2002). Decomposition of CWD can directly influence how rapidly forests become sinks for $\mathrm{C}$ following disturbance (Thornton et al., 2002). Although temperature and moisture can change following disturbance and this can accelerate rates of decomposition (Amiro, 2001), changes in the environment probably play a minor role in regulating CWD pool size compared with disturbance history. We believe that the amount of residual CWD following disturbance and its size and incorporation into the mineral soil play a key role in defining the wide range of variability in pool sizes in the youngest age class of forests (Fig. 4). Consequently, this variability in the youngest temperate age class is probably because of differences in forest management activities.

In old forests, the main factor regulating a change in CWD pool size is the continued recruitment of new CWD into this pool, not changes in the environmental factors that drive decomposition during succession or following disturbance. When old forests are harvested, it is primarily the storage term (pool size) of CWD that is altered in subsequent years, not the rate of decomposition. In other words, the pool declines primarily because recruitment of new CWD has halted, not because rates of decomposition are greatly altered. This is true for the forest floor as well (Yanai et al., 2003). Eventually, recruitment of significant amounts of new CWD begins as stands age and pools of CWD recover. This process explains the bowl-shaped trend of CWD seen in the temperate forest data (Fig. 4). High levels of CWD following disturbance in the youngest age class and in old-growth forests are also a trend observed in other studies (Spies et al., 1988; Sturtevant et al., 1997; Janisch \& Harmon, 2002). In boreal forests, CWD dynamics appear to be driven mostly by stand-replacing wildfires that reoccur on relatively short time steps (Kasischke \& Stocks, 2000); thus, pool sizes never account for as great a proportion of total ecosystem $\mathrm{C}$ as in temperate forests.

Total ecosystem C. Total ecosystem C pool sizes were synthesized from sites where all four pools were directly measured and reported following the criteria outlined in the methods. In the literature, it is very common for one or more of the four pools to go unmeasured at any given study site. Data depicted for each of the four pools and the ecosystem totals are somewhat independent because the data come from a

Table 2 Two estimates of total ecosystem carbon $\left(\mathrm{MgCha}^{-1}\right)$ for boreal, temperate, and tropical forest biomes

\begin{tabular}{|c|c|c|c|c|c|c|}
\hline \multirow[b]{2}{*}{ Age class } & \multicolumn{2}{|l|}{ Boreal } & \multicolumn{2}{|l|}{ Temperate } & \multicolumn{2}{|l|}{ Tropical } \\
\hline & Literature & Additive & Literature & Additive & Literature & Additive \\
\hline$A$ & $67 \pm 28$ & 161 & $121 \pm 27$ & 186 & $111 \pm 30$ & 125 \\
\hline$B$ & $98 \pm 45$ & 245 & $106 \pm 49$ & 169 & $131 \pm 63$ & 210 \\
\hline$C$ & $214 \pm 155$ & 171 & $189 \pm 58$ & 158 & - & 178 \\
\hline$D$ & $233 \pm 214$ & 210 & $240 \pm 36$ & 248 & - & 80 \\
\hline$E$ & $102 \pm 23$ & - & $537 \pm 335$ & 487 & $253 \pm 107$ & 328 \\
\hline
\end{tabular}

'Literature' refers to averages (and one standard deviation) of independent published field studies of total ecosystem carbon where all four pools were actually measured at each field site and 'additive' is the summation of mean values for the living biomass, organic soil horizons, soil, and coarse woody debris pools derived from the data compiled in this study. The number of observations by age class and biome are listed in Table 1 . There was insufficient data for age class $E$ of the boreal forests to calculate an 'additive' value. Age classes, in years, for the boreal biome are: $A=0-30 ; B=31-70, C=71-120 ; D=121-200 ; E=>200$, and for the temperate and tropical biomes: $A=0-10 ; B=11-30 ; C=31-70 ; D=71-120 ; E=121-200$. 
variety of different studies, sites, and locations. One way to check the validity of total ecosystem $C$ is to add the mean values for each of the four pools and compare these numbers with the totals actually measured. In general, totals developed by adding together the mean pool sizes compare quite well with the totals actually measured (Table 2). Exceptions include totals in the first two age classes of boreal forests and the first age class for the temperate forests (Table 2). For the boreal forests, this is caused by the fact that total ecosystem C was measured on a greater proportion of well-drained sites, while the mean soil $\mathrm{C}$ included a greater percentage of poorly drained sites, sites that accrue much higher levels of soil $\mathrm{C}$ than well-drained boreal forests (Gower et al., 1997). For young temperate forests (0-10-year age class), the measured and additive totals do not compare well because of the large pools of CWD in some temperate forests following harvest, which inflates the CWD mean in this age class $\left(74 \pm 88 \mathrm{MgCha}^{-1}\right)$. These three discrepancies also point out why we feel it is more appropriate to model biome changes in time based on median rather than mean pool size (Table 1, Fig. 4). However, in general, the measured and additive totals compare rather well (Table 2), with the exceptions noted.

\section{Conclusions}

Biome estimates of NPP and NEP peaked at intermediate ages and declined in the older age classes. NEP studies in mature forests are not necessarily good surrogates for young forests that are rapidly increasing their biomass and accruing $C$ in CWD and soil pools.

Heterotrophic soil respiration $\left(R_{\mathrm{h}}\right)$ depends fundamentally upon disturbance intensity, with the greatest amount of $R_{\mathrm{h}}$ occurring directly following disturbance in the youngest age class. Both temperate and boreal forests in the youngest age class had negative mean rates of NEP (source to the atmosphere) because rates of $R_{\mathrm{h}}$ were high. Understanding the processes controlling $R_{\mathrm{h}}$ following disturbance is critical to understanding time trends in NEP.

Total ecosystem respiration is highest when forests are relatively young and ecosystem respiration declines during the later stages of succession.

Disturbance history and the age class distribution of forests within a biome are very important in controlling rates of $\mathrm{C}$ cycling and storage. Additional mechanistic studies of NEP along chronosequences and historical reconstructions of land-use change are critical to improving our fundamental understanding of the terrestrial C cycle.

\section{Acknowledgements}

This synthesis was supported by NIGEC, a component of DOE/ BER's Program for Ecosystem Research, The USDA Forest Service, and NSF/DEB (Ecological Collaboratory Circuitry Program). D. Binkley and E. A. Paul provided logistical support, encouragement, and important insight.

\section{References}

Alban DH, Perala DA (1992) Carbon storage in Lake States aspen ecosystems. Canadian Journal of Forest Research, 22, 1107-1110.

Alban KG, Perala DA, Schlaegel BE (1978) Biomass and nutrient distribution in aspen, pine, and spruce stands on the same soil type in Minnesota. Canadian Journal of Forest Research, 8, 290-299.

Amiro BD (2001) Paired-tower measurements of carbon and energy fluxes following disturbance in the boreal forest. Global Change Biology, 7, 253-268.

Arajo AC, Nobre AD, Kruijt JA et al. (2002) Comparative measurements of carbon dioxide fluxes from two nearby towers in a central Amazonian rain forest: the Manaus LBA site. Journal of Geophysical Research, 107, 8090.

Arneth A, Kelliher FM, McSeneny TM et al. (1998) Assessment of annual carbon exchange in a water-stressed Pinus radiata plantation: an analysis based on eddy covariance measurements and an integrated biophysical model. Global Change Biology, 5, 531-545.

Baldocchi DD, Falge E, Gu L et al. (2001) FLUXNET: a new tool to study the temporal and spatial variability of ecosystemscale carbon dioxide, water vapor and energy flux densities. Bulletin of the American Meteorological Society, 82, 2415-2435.

Bashkin MA, Binkley D (1998) Changes in soil carbon following afforestation in Hawaii. Ecology, 79, 828-833.

Binkley D, Ryan MG (1998) Net primary production and nutrient cycling in replicated stands of Eucalyptus saligna and Albizia facaltaria. Forest Ecology and Management, 112, 79-85.

Bird MI, Santruckova H, Arneth A et al. (2002) Soil carbon inventories and carbon-13 on a latitude transect in Siberia. Tellus, 54B, 631-641.

Black TA et al. (1996) Annual cycles of $\mathrm{CO}_{2}$ and water vapor fluxes above and within a boreal aspen stand. Global Change Biology, 2, 219-230.

Borman FH, Likens GE (1979) Pattern and Process in Forested Ecosystems. Springer-Verlag, New York.

Brown S, Lugo AE (1990) Tropical secondary forests. Journal of Tropical Ecology, 6, 1-32.

Cadish G, Giller KE (1997) Driven by Nature: Plant Litter Quality and Decomposition. CAB International, Wallingford.

Carey EV, Sala A, Keane R et al. (2001) Are old forests underestimated as global carbon sinks? Global Change Biology, 7, 339-344.

Carmona MR, Armesto JJ, Aravena JC et al. (2002) Coarse woody debris biomass in successional and primary temperate forests in Chiloé Island, Chile. Forest Ecology and Management, 164, 265-275.

Carswell FE, Costa AL, Palheta M et al. (2002) Seasonality in $\mathrm{CO}_{2}$ and $\mathrm{H}_{2} \mathrm{O}$ flux at an eastern Amazonia rain forest. Journal of Geophysical Research, D20, 8076. 
Cerri CC, Volkoff B, Anreaux F (1991) Nature and behavior of organic matter in soils under natural forest and after deforestation, burning and cultivation, near Manaus. Forest Ecology and Management, 38, 247-257.

Chapin FS III, Matson PA, Mooney HA (2002) Principles of Terrestrial Ecosystem Ecology. Springer, New York.

Clark DA, Brown S, Kicklighter DW et al. (2001) Net primary production in tropical forests: an evaluation and synthesis of existing field data. Ecological Applications, 11, 371-384.

Clark DA, Piper SC, Keeling CD et al. (2003) Tropical rain forest tree growth and atmospheric carbon dynamics linked to interannual temperature variation during 1984-2000. Proceedings of the National Academy of Sciences USA, 100, 5852-5857.

Clark DB, Clark DA, Brown S et al. (2002) Stocks and flows of coarse woody debris across a tropical rain forest nutrient and topography gradient. Forest Ecology and Management, 164, 237-248.

Clark KL, Gholz HL, Moncrieff JB et al. (1999) Environmental controls over net exchanges of carbon dioxide from contrasting Florida ecosystems. Ecological Applications, 9, 936-948.

Covington WW (1981) Changes in forest floor organic matter and nutrient content following clear cutting in northern hardwoods. Ecology, 62, 41-48.

Cuevas E, Brown S, Lugo AE (1991) Above- and belowground organic matter storage and production in a tropical pine plantation and a paired broadleaf secondary forest. Plant and Soil, 135, 257-268.

Curtis PS, Hanson PJ, Bolstad P et al. (2002) Biometric and eddy covariance based estimates of annual carbon storage in five eastern North American deciduous forests. Agricultural and Forest Meteorology, 113, 3-19.

Davis MR, Allen RB, Clinton PW (2002) Carbon storage along a stand development sequence in a New Zealand Nothofagus forest. Forest Ecology and Management, 177, 313-321.

De Camargo PB, Trumbore SE, Martinelli LA et al. (1999) Soil carbon dynamics in regrowing forest of eastern Amazonia. Global Change Biology, 5, 693-702.

Dixon RK (1994) Carbon pools and flux of global forest ecosystems. Science, 263, 185-190.

Ehman JL, Schmid HP, Grimmond CSB et al. (2002) An initial intercomparison of micrometeorological and ecological inventory estimates of carbon exchange in a mid-latitude deciduous forest. Global Change Biology, 8, 575-589.

Euskirchen ES, Chen J, Li H et al. (2002) Modeling landscape net ecosystem productivity (LandNEP) under alternative management regimes. Ecological Modelling, 154, 75-91.

Fan SM, Wofsy SC, Bakwin PS et al. (1990) Atmospherebiosphere exchange of $\mathrm{CO}_{2}$ and $\mathrm{O}_{3}$ in the Central Amazon forest. Journal of Geophysical Research, 95, 12851-12864.

Finér L, Mannerkoski S, Piirainen S et al. (2003) Carbon and nitrogen pools in an old-growth, Norway spruce mixed forest in eastern Finland and changes associated with clear-cutting. Forest Ecology and Management, 174, 51-63.

Gaudinski JB, Trumbore SE, Davidson EA, Zheng S. (2000) Soil carbon cycling in a temperate forest: radio-carbon-based estimates of residence times, sequestration rates and partitioning of fluxes. Biogeochemistry, 51, 33-69.
Gholz HL, Fisher RF (1982) Organic matter production and distribution in slash pine (Pinus elliottii) plantations. Ecology, 63, 1827-1839.

Goodburn JM, Lorimer CG (1998) Cavity trees and coarse woody debris in old-growth and managed northern hardwood forests in Wisconsin and Michigan. Canadian Journal of Forest Research, 28, 427-438.

Goulden ML, Wofsy SC, Harden JW et al. (1998) Sensitivity of boreal forest carbon balance to soil thaw. Science, 279, 214-217.

Gower ST, Gholz HL, Nakane K et al. (1994) Production and carbon allocation patterns of pine forests. Ecological Bulletin, 43, 115-135.

Gower ST, Krankina O, Olson RJ et al. (2001) Net primary production and carbon allocation patterns of boreal forest ecosystems. Ecological Applications, 11, 1395-1411.

Gower ST, Vogt KA, Grier CC (1992) Carbon dynamics of rocky mountain douglas-fir: influence of water and nutrient availability. Ecological Monographs, 62, 43-66.

Gower ST, Vogel JG, Norman JM et al. (1997) Carbon distribution and aboveground net primary production in aspen, jack pine, and black spruce stands in Saskatchewan and Manitoba, Canada. Journal of Geophysical Research, 102, 29,029-29,041.

Grace J, Lloyd J, McIntyre J et al. (1995) Carbon dioxide uptake by an undisturbed tropical rain forest in Southwest Amazonia, 1992 to 1993. Science, 270, 778-780.

Grace J, Malhi Y, Higuchi N et al. (2001) Productivity of tropical rain forests. In: Terrestrial Global Productivity (eds Roy J, Saugier B, Mooney HA), pp. 401-426. Academic Press, San Diego, CA.

Grier CC, Elliott J, McCullough DG (1992) Biomass distribution and productivity of Pinus edulis-Juniperus monosperma woodlands of north-central Arizona. Forest Ecology and Management, 50, 331-350.

Gu L, Baldocchi DD, Wofsy SC et al. (2003) Responses of a deciduous forest to the Mount Pinatubo eruption: enhanced photosynthesis. Science, 299, 2035-2039.

Hadley JL, Schedlbauer JL (2002) Carbon exchange of an oldgrowth eastern hemlock (Tsuga canadensis) forest in central New England. Tree Physiology, 22, 1079-1093.

Hanson PJ, Edwards NT, Garten CT et al. (2000) Separating root and soil microbial contributions to soil respiration: a review of methods and observations. Biogeochemistry, 48, 115-146.

Harden JW, O'Neill KP, Trumbore SE et al. (1997) Moss and soil contributions to the annual net carbon flux of a maturing boreal forest. Journal of Geophysical Research, 102, 28,805-28,816.

Harmon ME, Ferrell WK, Franklin JF et al. (1986) Ecology of coarse woody debris in temperate ecosystems. Advances in Ecological Research, 15, 133-302.

Harmon ME, Ferrell WK, Franklin JF (1990) Effects on carbon storage of conversion of old-growth forests to young forests. Science, 247, 699-702.

Harmon ME, Whigham F, Sexton J et al. (1995) Decomposition and mass of woody detritus in the dry tropical forests of the northeastern Yucatan Peninsula, Mexico. Biotropica, 27, 305316.

Hix DM, Barnes BV (1984) Effects of clear-cutting on the vegetation and soil of an eastern hemlock dominated 
ecosystem, western Upper Michigan. Canadian Journal of Forest Research, 14, 914-923.

Högberg P, Nordgren A, Buchmann N et al. (2001) Large-scale forest girdling shows that current photosynthesis drives soil respiration. Nature, 411, 789-792.

Hooker TD, Compton JE (2003) Forest ecosystem carbon and nitrogen accumulation during the first century after agricultural abandonment. Ecological Applications, 13, 299-313.

Hoover CM, Magrini KA, Evans RJ (2002) Soil carbon content and character in an old-growth forest in northwestern Pennsylvania: a case study introducing pyrolysis molecular beam mass spectrometry (py-MBMS). Environmental Pollution, 116, S269-S275.

Houghton RA (2001) Global terrestrial productivity and carbon balance. In: Terrestrial Global Productivity (eds Roy J, Saugier B, Mooney HA), Academic Press, San Diego, CA.

Houghton RA, Skole DL, Lefkowitz DS (1991) Changes in the landscape of Latin America between 1850 and 1985 II. Net release of $\mathrm{CO}_{2}$ to the atmosphere. Forest Ecology and Management, 38, 173-199.

Huntington TG, Ryan DF, Hamburg SP (1988) Estimating soil nitrogen and carbon pools in a northern hardwood forest ecosystem. Soil Science Society of America Journal, 52, 1162-1167.

Idol TW, Figler RA, Pope PE et al. (2001) Characterization of coarse woody debris across a 100 year chronosequence of upland oak-hickory forests. Forest Ecology and Management, 149, 153-161.

Jackson RB, Schenk HJ, Jobbágy EG et al. (2000) Belowground consequences of vegetation change and their treatment in models. Ecological Applications, 10, 470-483.

Janisch JE, Harmon ME (2002) Successional changes in live and dead wood carbon stores: implications for net ecosystem productivity. Tree Physiology, 22, 77-89.

Jobbagy EG, Jackson RB (2000) The vertical distribution of soil organic carbon and its relation to climate and vegetation. Ecological Applications, 10, 423-436.

Johnson DW, Curtis PS (2001) Effects of forest management on soil carbon and nitrogen storage: meta analysis. Forest Ecology and Management, 140, 227-238.

Kajimoto T, Matsuura Y, Sofronov MA et al. (1999) Above- and belowground biomass and net primary productivity of a Larix gmelinii stand near Tura, central Siberia. Tree Physiology, 19, 815-822.

Kasischke ES, Stocks BJ (2000) Fire, Climate Change, and Carbon Cycling in the Boreal Forest. Springer, New York.

Kaye JP, Resh SC, Kaye MW et al. (2000) Nutrient and carbon dynamics in a replacement series of Eucalyptus and Albizia trees. Ecology, 81, 3267-3273.

Klopatek JM (2002) Belowground carbon pools and processes in different age stands of Douglas-fir. Tree Physiology, 22, 197-202.

Knohl A, Schulze E-D, Kolle O, Buchmann N (2003) Large carbon uptake by an unmanaged 250-year-old deciduous forest in Central Germany. Agricultural and Forest Meteorology, 118, 151-169.

Körner C (2003) Slow in, rapid out-carbon flux studies and Kyoto targets. Science, 300, 1242-1243.
Krause H (1998) Forest floor mass and nutrients in two chronosequences of plantations: jack pine vs. black spruce. Canadian Journal of Soil Science, 78, 77-83.

Laiho R, Sanchez F, Tiarks A et al. (2003) Impacts of intensive forestry on early rotation trends in site carbon pools in the southeastern US. Forest Ecology and Management, 174, 177-189.

Law BE, Sun OJ, Campbell J et al. (2003) Changes in carbon storage and fluxes in a chronosequence of Ponderosa pine. Global Change Biology, 9, 510-524.

Law BE, Falge E, Gu L, Baldocchi DD, Bakwin P, Berloigier P, Davis K, Dolman AJ, Falk M, Fuentes JD, Goldstein A, Granier A, Grelle A, Hollinger D, Janssens IA, Jarvis P, Jensen NO, Katul G, Manli Y, Matteuchi G, Meyers T, Monson R, Munger W, Oechel W, Olson R, Pilegaard K, Paw UKT, Thorgeirsson H, Valentini R, Verma S, Vesala T, Wilson K, Wofsy S (2002) Environmental controls over carbon dioxide and water vapor exchange of terrestrial vegetation. Agricultural and Forest Meteorology, 113, 97-120.

Lee X, Fuentes JD, Staebler RM et al. (1999) Long-term observation of the atmospheric exchange of $\mathrm{CO}_{2}$ with a temperate deciduous forest. Journal of Geophysical Research, 104, 15,975-15,984.

Liechty HO, Jurgensen MF, Mroz GD et al. (1997) Pit and mound topography and its influence on storage of carbon, nitrogen, and organic matter within an old-growth forest. Canadian Journal of Forest Research, 27, 1992-1997.

Litton CM, Ryan MG, Tinker DB et al. (2003) Belowground and aboveground biomass in young postfire lodgepole pine forests of contrasting tree density. Canadian Journal of Forest Research, 33, 351-363.

Lloyd J, Shibistova O, Zolotoukhine D et al. (2002) Seasonal and annual variations in the photosynthetic productivity and carbon balance of a central Siberian pine forest. Tellus, 54B, 590-610.

Lodhiyal LS, Lodhiyal N (1997) Variation in biomass and net primary productivity in short rotation high-density central Himalayan poplar plantations. Forest Ecology and Management, 98, 167-179.

Lodhiyal N, Lodhiyal LS (2003) Biomass and net primary productivity of Bhabar Shisham forests in central Himalaya, India. Forest Ecology and Management, 176, 217-235.

Loescher HW, Oberhauer SF, Gholz HL et al. (2003) Environmental controls on net ecosystem-level productivity in a Central American tropical wet forest. Global Change Biology, 9, 396-412.

Lugo AE (1992) Comparison of tropical tree plantations with secondary forests of similar age. Ecological Monographs, 62, $1-41$.

Madeira MV, Fabio A, Pereira JS et al. (2002) Changes in carbon stocks in Eucalyptus globulus Labill. plantations induced by different water and nutrient availability. Forest Ecology and Management, 171, 75-85.

Malhi Y, Baldocchi DD, Jarvis PG (1999) The carbon balance of tropical, temperate and boreal forests. Plant, Cell and Environment, 22, 715-740.

Malhi Y, Nobre AD, Grace J (1998) Carbon dioxide transfer over a Central Amazonia rain forest. Journal of Geophysical Research, D24, 31593-31612. 
Martinez-Yrizar A, Maass JM, Perez-Jimenz LA et al. (1996) Net primary productivity of a tropical deciduous forest ecosystem in western Mexico. Journal of Tropical Ecology, 12, 169-175.

Milyukova IM, Kolle O, Varlagin AV et al. (2002) Carbon balance of a southern taiga spruce stand in European Russia. Tellus, 54B, 429-442.

Monson RK, Turpinseed AA, Sparks JP et al. (2002) Carbon sequestration in a high-elevation, subalpine forest. Global Change Biology, 8, 459-478.

Morris AR (1995) Forest floor accumulation, nutrition and productivity of Pinus patula in the Usutu Forest, Swaziland. Plant and Soil, 168-169, 271-278.

Morrison IK (1990) Organic matter and mineral distribution in an old-growth Acer saccharum forest near the northern limit of its range. Canadian Journal of Forest Research, 20, 1332-1342.

Mund M, Kummetz E, Hein M et al. (2002) Growth and carbon stocks of a spruce forest chronosequence in central Europe. Forest Ecology and Management, 171, 275-296.

Myneni RB, Keeling CD, Tucker CJ et al. (1997) Increased plant growth in the northern high latitudes from 1981-1991. Nature, 386, 698-702.

Odum EP (1969) The strategy of ecosystem development. Science, 164, 262-270.

Page SE, Slegert F, Rieley JO et al. (2002) The amount of carbon released from peat and forest fires in Indonesia during 1997. Nature, 420, 61-65.

Perala DA, Alban DH (1982) Biomass, nutrient distribution and litterfall in Populus, Pinus, and Picea stands on two different soils in Minnesota. Plant and Soil, 64, 177-192.

Pregitzer KS, Palik BJ (1997) Changes in ecosystem carbon 46 years after establishing red pine (Pinus resinosa Ait.) on abandoned agricultural land in the Great Lakes region. In: Soil Organic Matter in Temperate Agroecosystems, Long-Term Experiments in North America (eds Paul EA et al.), pp. 263-270. CRC Press, Boca Raton, FL.

Raich JW (1983) Effects of forest conversion on the carbon budget of a tropical soil. Biotropica, 15, 177-184.

Rapalee G, Trumbore SE, Davidson EA et al. (1998) Soil carbon stocks and their rates of accumulation and loss in the boreal forest landscape. Global Biogeochemical Cycles, 12, 687-701.

Reich PB, Bolstad P (2001) Productivity of evergreen and deciduous temperate forests. In: Terrestrial Global Productivity (eds Roy J, Saugier B, Mooney HA), pp. 245-283. Academic Press, San Diego, CA.

Reichle DE (1981) Dynamic Properties of Forest Ecosystems. Cambridge University Press, Cambridge.

Resh SC, Binkley D, Parrotta JA (2002) Great soil carbon sequestration under nitrogen-fixing trees compared with Eucalyptus species. Ecosystems, 5, 217-231.

Rhoades CC, Eckert GE, Coleman DC (2000) Soil carbon differences among forest, agriculture, and secondary vegetation in lower montane Ecuador. Ecological Applications, 10, 497-505.

Rice JA (1995) Mathematical Statistics and Data Analysis. Duxbury Press, Belmont, CA.

Ruark GA, Bockheim JG (1988) Biomass, net primary productivity, and nutrient distribution for an age sequence of Populus tremuloides ecosystems. Canadian Journal of Forest Research, 18, 435-443.

Ryan MG, Binkley D, Fownes JH (1997) Age-related decline in forest productivity: pattern and process. Advances in Ecological Research, 27, 213-262.

Saigusa N, Yamamoto S, Murayama S et al. (2002) Gross primary production and net ecosystem exchange of a cool-temperate deciduous forest estimated by the eddy covariance method. Agricultural and Forest Meteorology, 112, 203-215.

SAS Institute (1990) SAS User's Guide Version 6.0. SAS Institute, Cary, NC.

Schimel D, Melillo J, Tian $\mathrm{H}$ et al. (2000) Contribution of increasing $\mathrm{CO}_{2}$ and climate to carbon storage by ecosystems in the United States. Science, 287, 2004-2006.

Schmid HP, Grimmond CSB, Cropley F et al. (2000) Measurements of $\mathrm{CO}_{2}$ and energy fluxes over a mixed hardwood forest in the mid-western USA. Agricultural and Forest Meteorology, 103, 357-374.

Schulze E-D, Lloyd J, Kelliher FM (1999) Productivity of forests in the Eurosiberian boreal region and their potential to act as a carbon sink - a synthesis. Global Change Biology, 5, 703-772.

Schulze E-D, Valentini R, Sanz M-J (2002) The long way from Kyoto to Marrakesh: implications of the Kyoto Protocol negotiations for global ecology. Global Change Biology, 8, 505-518.

Schulze E-D, Wirth C, Heimann M (2000) Managing forests after Kyoto. Science, 289, 2058-2059.

Schuur EAG, Matson PA (2001) Net primary productivity and nutrient cycling across a mesic to wet precipitation gradient in Hawaiian montane forest. Oecologia, 128, 431-442.

Scott NA, Tate KR, Ford-Robertson J et al. (1999) Soil carbon storage in plantation forests and pastures: land-use change implications. Tellus, 51B, 326-335.

Six J, Conant RT, Paul EA et al. (2002) Stabilization mechanisms of soil organic matter: implications for C-saturation of soils. Plant and Soil, 241, 155-176.

Smith CK, Oliveira FA, Gholz HL et al. (2002) Soil carbon stocks after forest conversion to tree plantations in lowland Amazonia, Brazil. Forest Ecology and Management, 164, 257-263.

Smithwick EAH, Harmon ME, Remillard SM et al. (2002) Potential upper bounds of carbon stores in forests of the Pacific Northwest. Ecological Applications, 12, 1303-1317.

Soil Survey Staff (1975) Soil Taxonomy. USDA Agricultural Handbook, Vol. 436. U.S. Government Printing Office, Washington, DC.

Spies TA, Franklin JF, Thomas TB (1988) Coarse woody debris in Douglas-fir forests of western Oregon and Washington. Ecology, 69, 1698-1072.

Street JM (1982) Changes of carbon inventories in live biomass and detritus as a result of the practice of shifting agriculture and the conversion of forest to pasture: case studies in Peru, New Guinea, and Hawaii. In: Geography and the Third World (eds Ahmad I, Jahi J), pp. 249-258. Penerbit Universiti, Kebangsaan, Malaysia.

Sturtevant BR, Bissonette JA, Long JN et al. (1997) Coarse woody debris as a function of age, stand structure, and disturbance in boreal Newfoundland. Ecological Applications, 7, 702-712.

Sundarapandian SM, Chandrasekaran S, Swamy PS (1999) Variations in fine root biomass and net primary productivity 
due to conversion of tropical forests into forest plantations. Tropical Ecology, 40, 305-313.

Thornton PE, Law BE, Gholz HL et al. (2002) Modeling and measuring the effects of disturbance history and climate on carbon and water budgets in evergreen needleleaf forests. Agricultural and Forest Meteorology, 113, 185-222.

Townsend AR, Vitousek PM, Trumbore SE (1995) Soil organic matter dynamics along gradients in temperature and land use on the island of Hawaii. Ecology, 76, 721-733.

Trumbore S (2000) Age of soil organic matter and soil respiration: radiocarbon constraints on belowground $\mathrm{C}$ dynamics. Ecological Applications, 10, 399-411.

Trumbore SE, Davidson EA, De Camargo PB et al. (1995) Belowground cycling of carbon in forests and pastures of Eastern Amazonia. Global Biogeochemical Cycles, 9, 515-528.

Trumbore SE, Harden JW (1997) Accumulation and turnover of carbon in organic and mineral soils of the BOREAS northern study area. Journal of Geophysical Research, 102, 28,817-28,830.

Valentini R, de Angelis P, Matteucci G et al. (1996) Seasonal net carbon dioxide exchange of a beech forest with the atmosphere. Global Change Biology, 2, 199-208.

Valentini R, Matteucci G, Dolman AJ et al. (2000) Respiration as the main determinant of carbon balance in European forests. Nature, 404, 861-865.

Van Cleve K, Oliver L, Schlentner R et al. (1983) Productivity and nutrient cycling in taiga forests. Canadian Journal of Forest Research, 13, 747-766.

Van Cleve K, Viereck L (1981) Forest succession in relation to nutrient cycling in the boreal forest of Alaska. In: Forest Succession, Concepts and Application (eds West DC, Shugart HH, Botkin DB), pp. 184-211. Springer-Verlag, New York.

Van Cleve K, Viereck LA, Schlentner RL (1971) Accumulation of nitrogen in alder (Alnus) ecosystems near Fairbanks, Alaska. Arctic and Alpine Research, 3, 101-114.

Van Dam D, Veldkamp E, Van Breemen N (1997) Soil organic carbon dynamics: variability with depth in forested and deforested soils under pasture in Costa Rica. Biogeochemistry, 39, 343-375.

Vitorello VA, Cerri CC, Andreux F et al. (1989) Organic matter and natural carbon-13 distribution in forested and cultivated oxisols. Soil Science Society of America Journal, 53, 773-778

Vogt K (1991) Carbon budgets of temperate forest ecosystems. Tree Physiology, 9, 69-86.

Vogt KA (1983) Organic matter and nutrient dynamics in forest floors in young and mature Abies amabilis stands in western Washington. Ecological Monographs, 53, 139-157.

Wang C, Bond-Lamberty B, Gower ST (2002) Environmental controls on carbon dioxide flux from black spruce coarse woody debris. Oecologia, 132, 374-381.
Webber BD (1977) Biomass and nutrient distribution patterns in a young Pseudotsuga menziesii ecosystem. Canadian Journal of Forest Research, 7, 326-334.

Weber MG, Methven IR, Van Wagner CE (1985) The effect of forest floor manipulation on nitrogen status and tree growth in an eastern Ontario jack pine ecosystem. Canadian Journal of Forest Research, 15, 313-318.

Whittaker RH (1974) The Hubbard Brook ecosystem study: forest biomass and production. Ecological Monographs, 44, 233-254

Wirth C (2002) Beyond annual budgets: carbon flux at different temporal scales in fire-prone Siberian Scots pine forests. Tellus, 54B, 611-630.

Woomer PL, Palm CA, Alegre J (2000) Slash- and-burn effects on carbon stocks in the humid tropics. In: Global Climate Change and Tropical Ecosystems (eds Lal R, Kimble JM, Stewart BA), pp. 99-115. CRC Press, Boca Raton, FL.

Yamamoto S, Murayama S, Saigusa N et al. (1999) Seasonal and inter-annual variation of $\mathrm{CO}_{2}$ flux between a temperate forest and the atmosphere in Japan. Tellus, 51B, 402-413.

Yanai RD (2000) Challenges of measuring forest floor organic matter dynamics: repeated measures from a chronosequence. Forest Ecology and Management, 138, 273-283.

Yanai RD, Currie WS, Goodale CL (2003) Soil carbon dynamics after forest harvest: an ecosystem paradigm reconsidered. Ecosystems, 6, 197-212.

Zak DR, Pregitzer KS (1998) Integration of ecophysiological and biogeochemical approaches to ecosystem dynamics. In: Successes, Limitations and Frontiers in Ecosystem Science (eds Pace M, Groffman L), pp. 372-403. Springer-Verlag, New York.

\section{Appendix A}

Pools and fluxes of selected components of the forest carbon cycle for boreal, temperate, and tropical forests (arranged alphabetically by reference within each grouping). Pools are in units of $\mathrm{MgCha}^{-1}$, and fluxes are in $\mathrm{MgCha}{ }^{-1} \mathrm{yr}^{-1}$. An asterisk $\left(^{*}\right)$ after the reference indicates that the data are from a chronosequence study. When different ecosystem types are reported within one reference, they are separated by commas. Mixed ecosystem types (e.g., several different types of dominant tree species in one ecosystem) are indicated by a dash between the various cover types. Positive NEP values indicate a $C$ sink (see Table A1). 


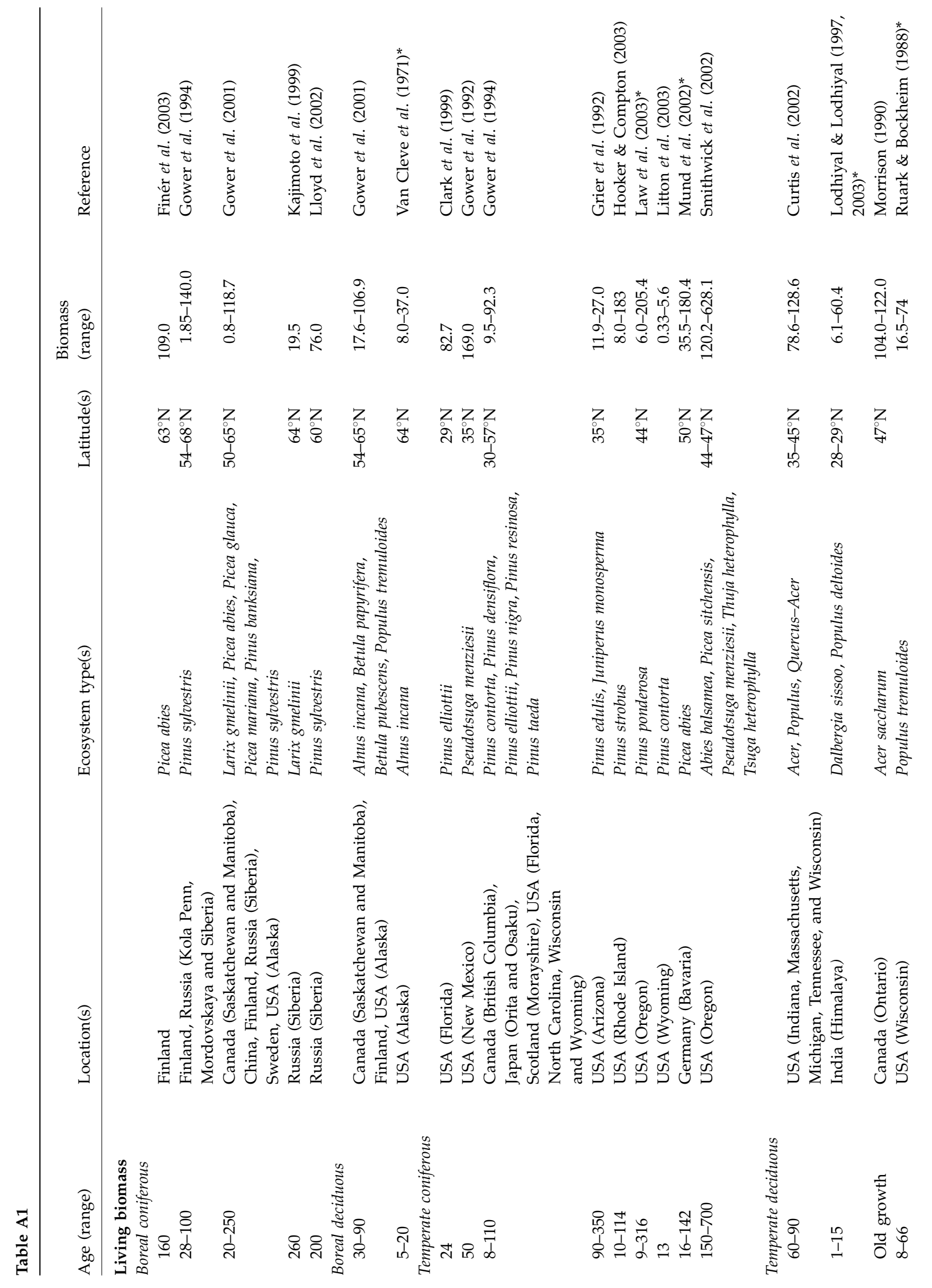




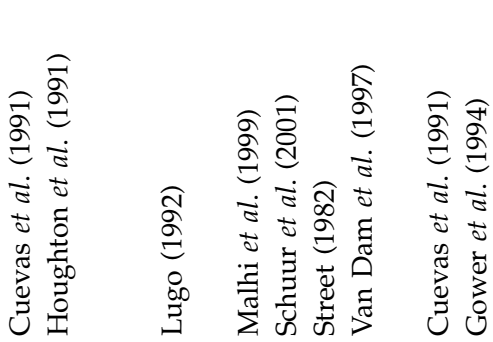

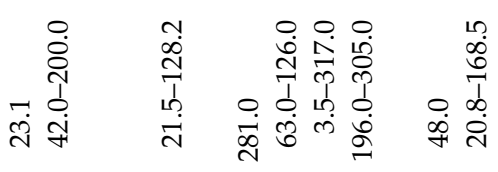

$\begin{array}{lll}z & n \\ \infty & \infty & \infty \\ \infty & \infty & \sim\end{array}$
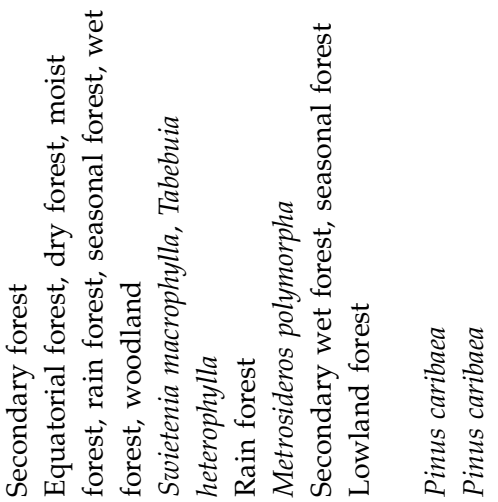

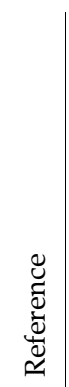

ชิ

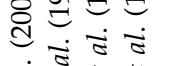

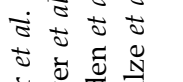

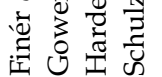

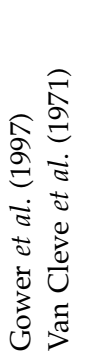

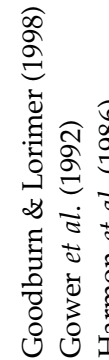

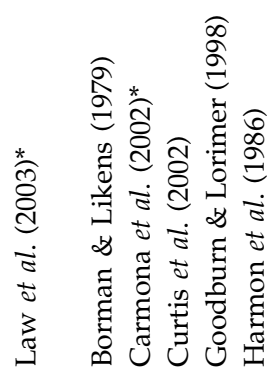

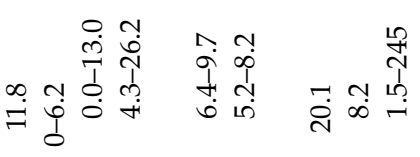

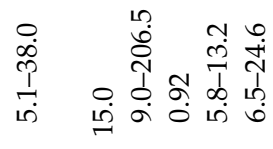

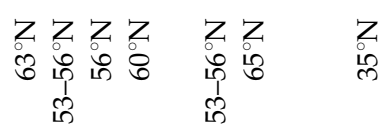

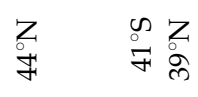
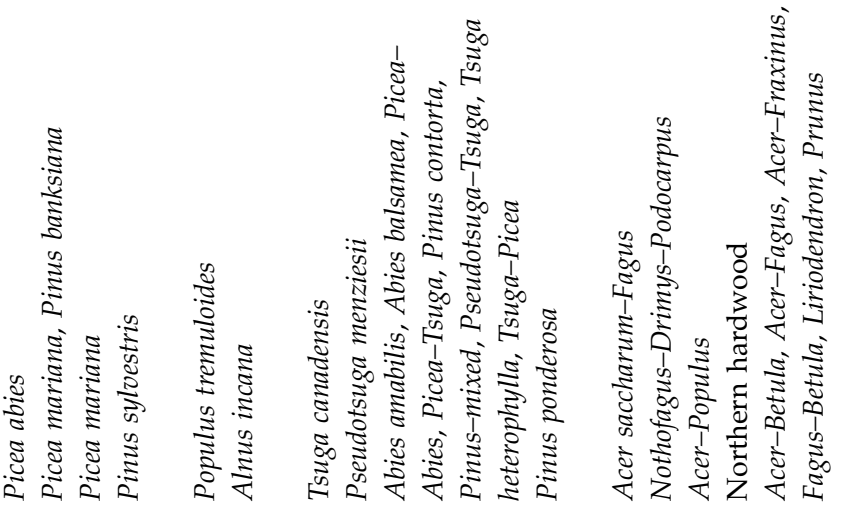

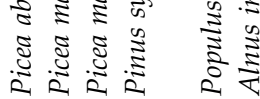

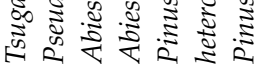

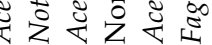
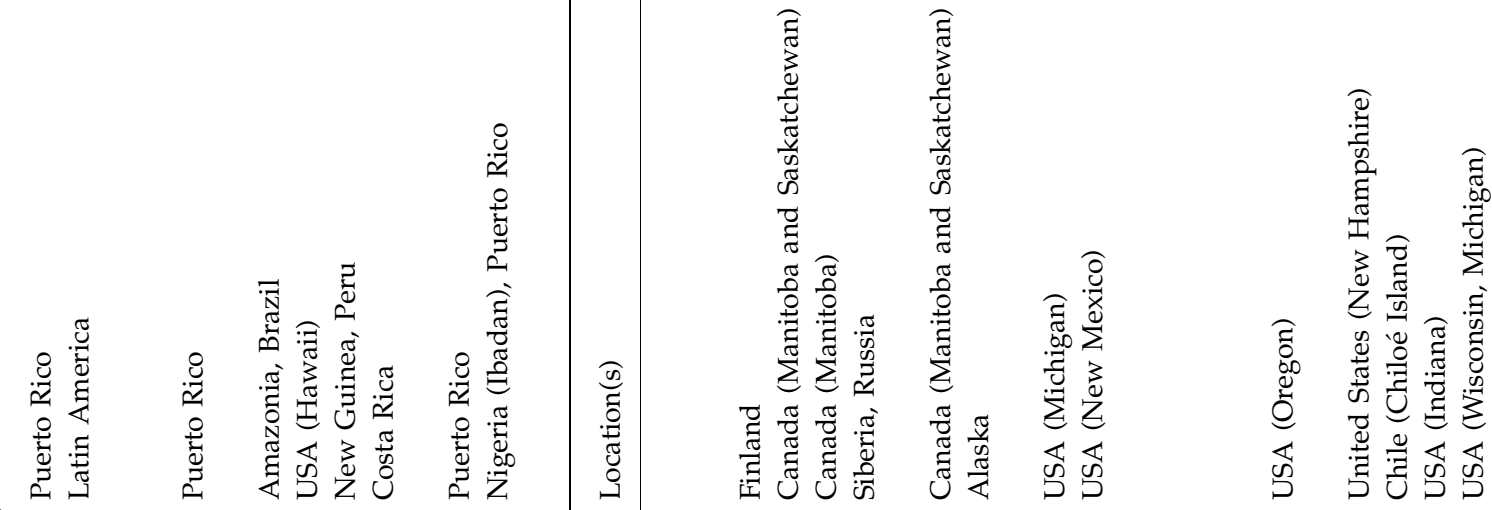

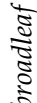

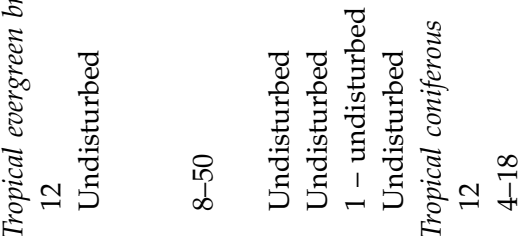

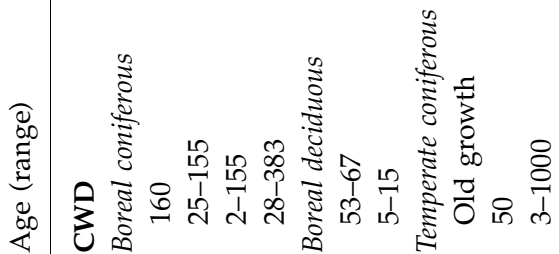

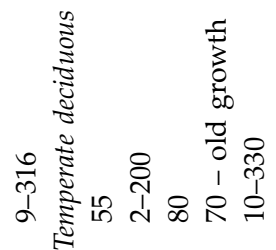




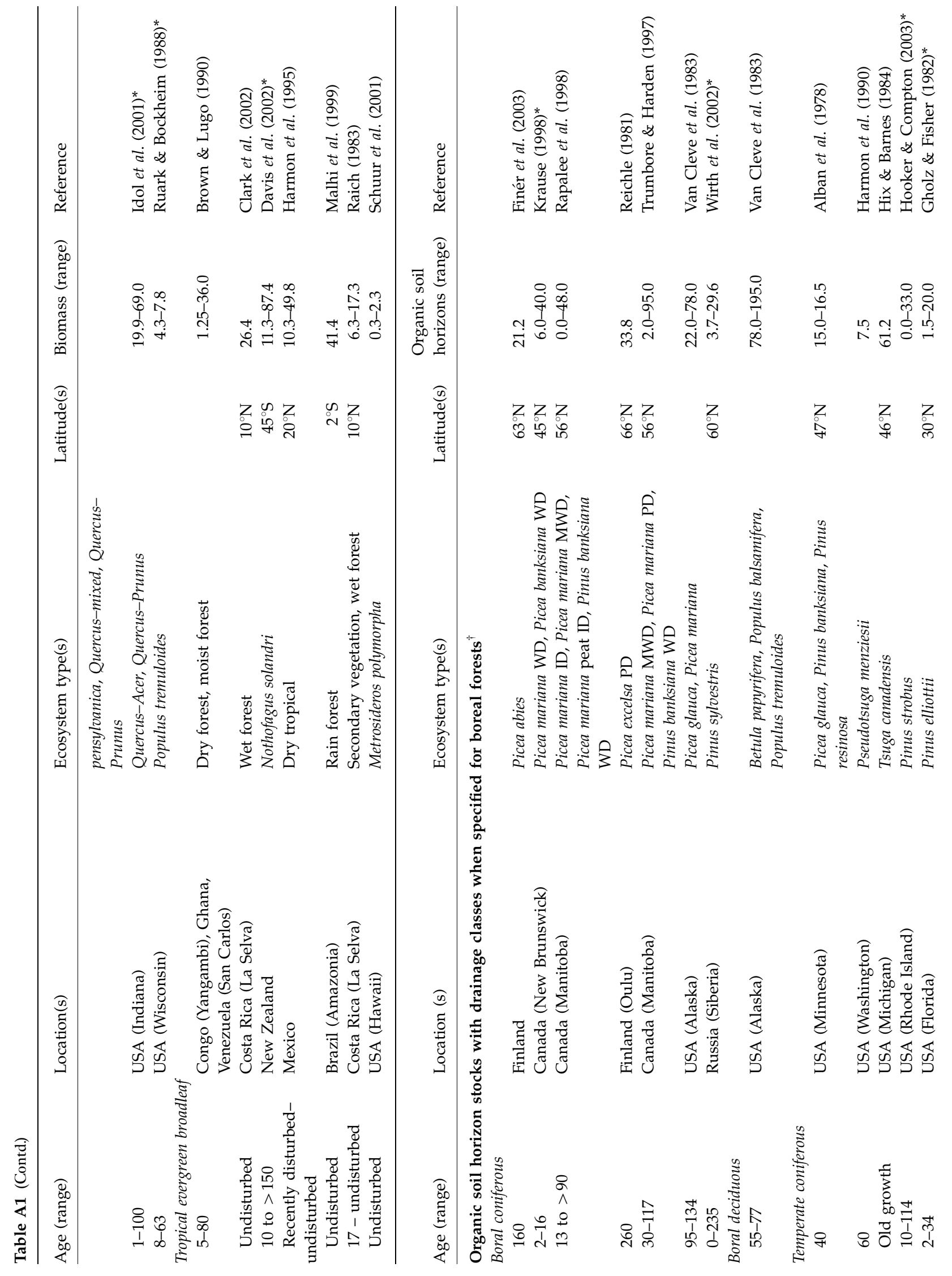




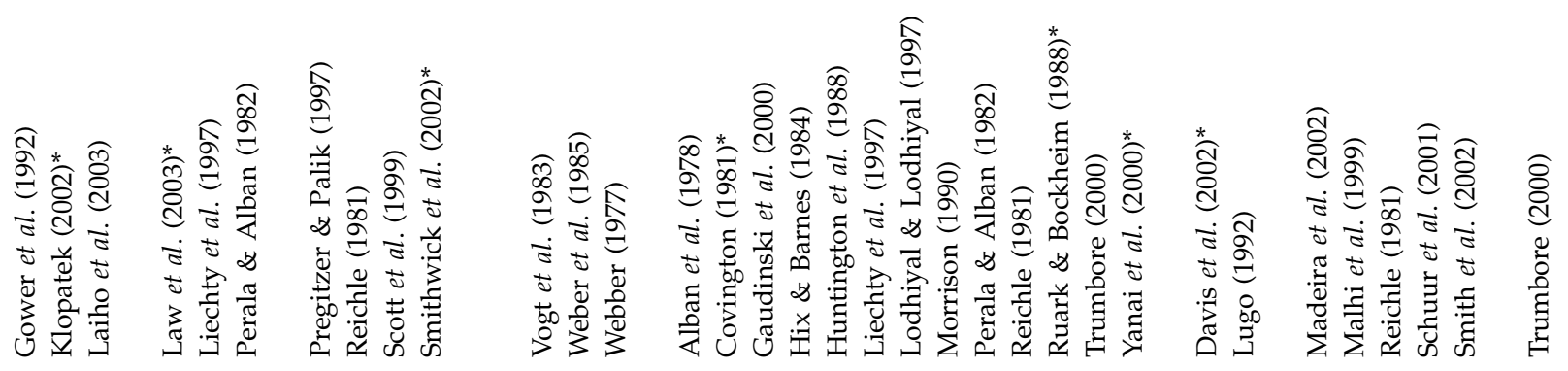

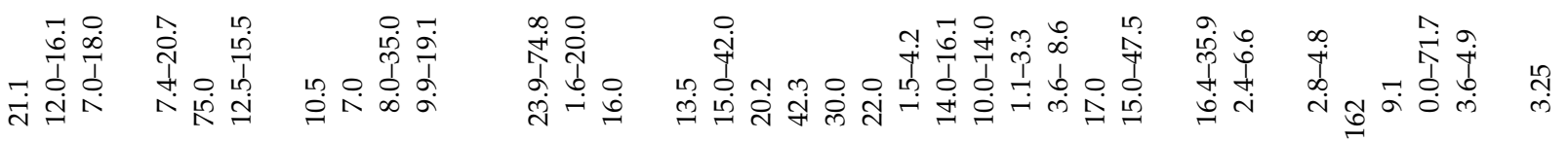

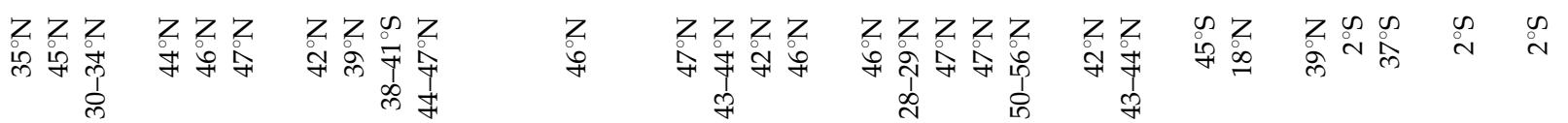

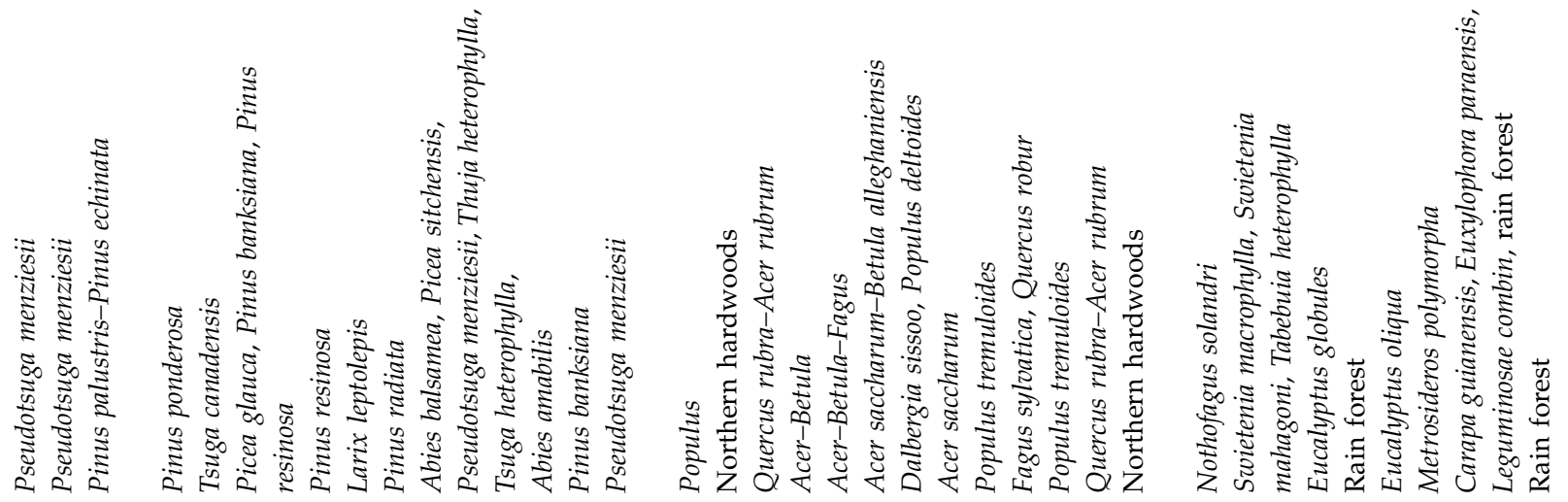

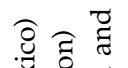

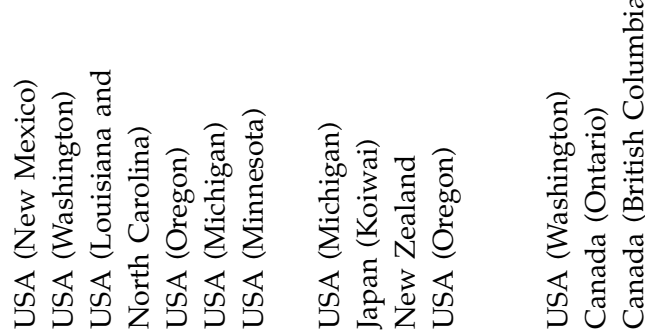

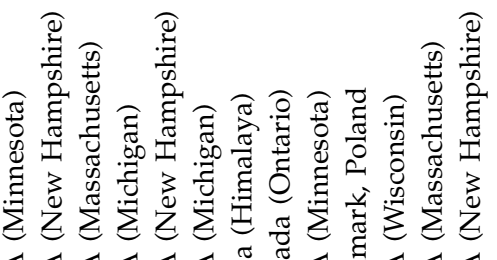

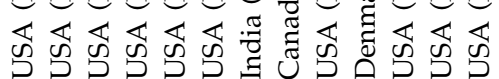

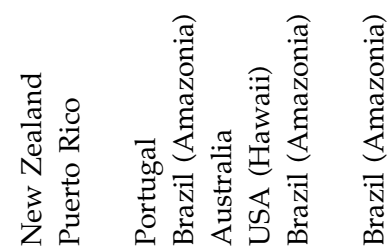

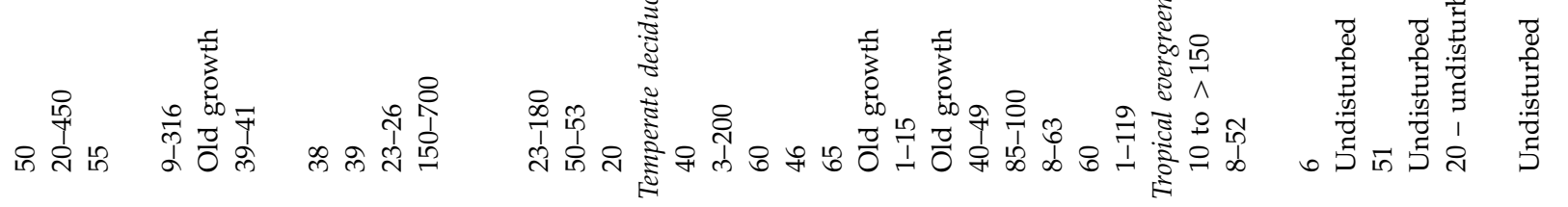




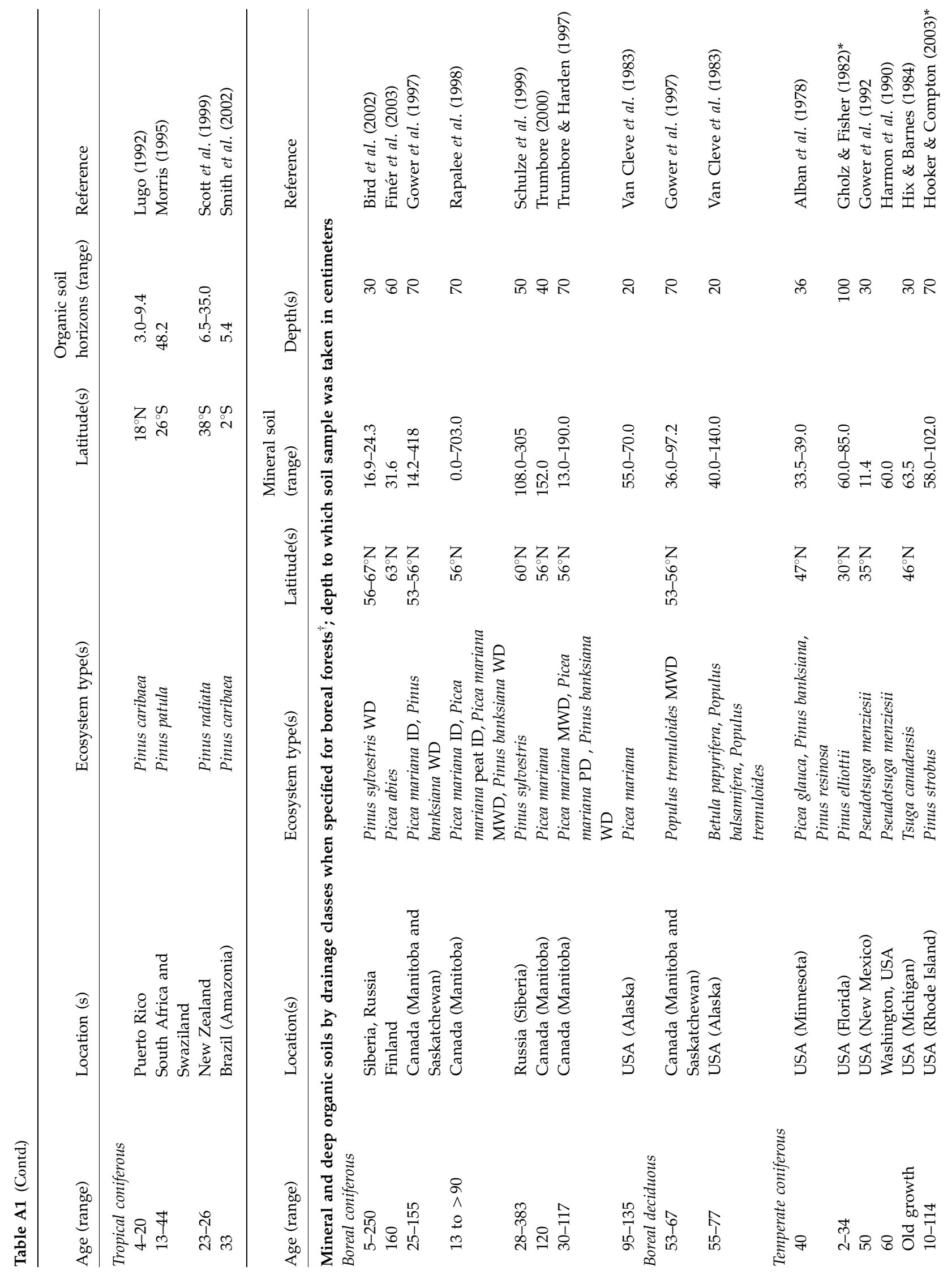




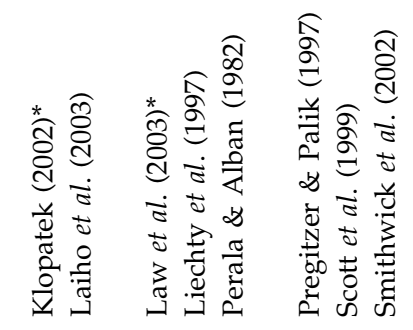

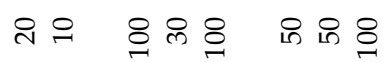

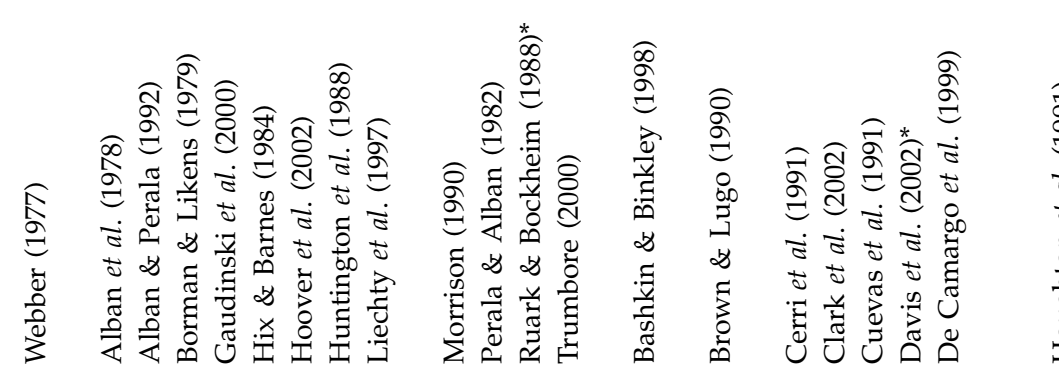

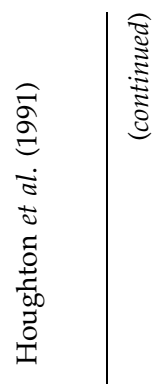

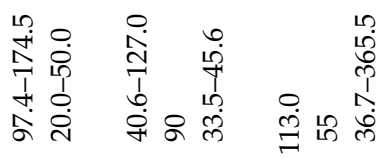

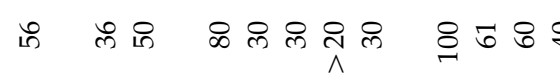

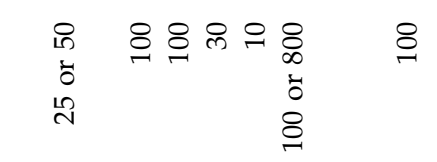

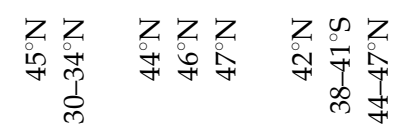

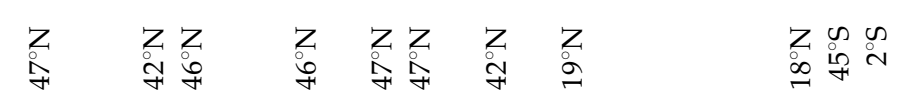

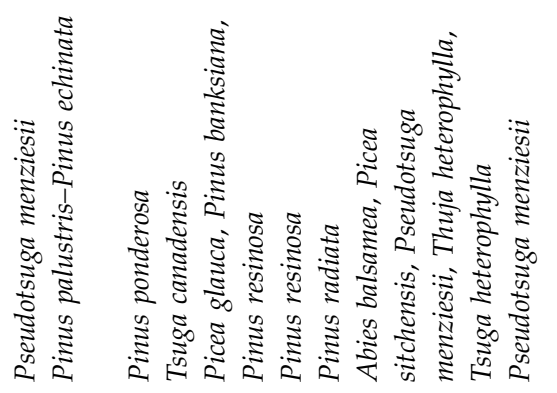

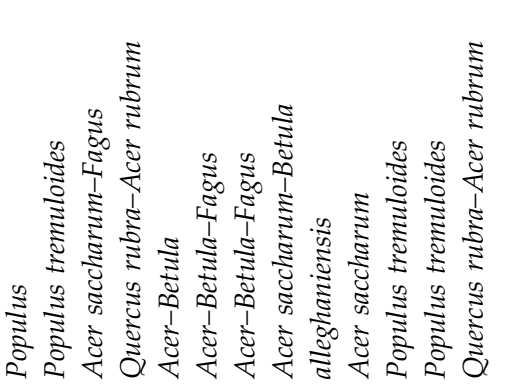

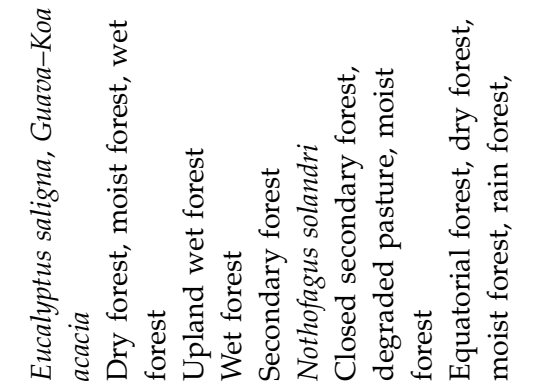

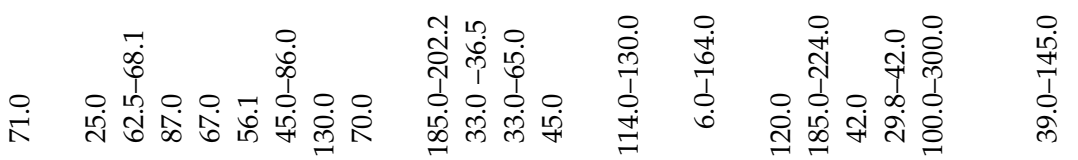
(n) 


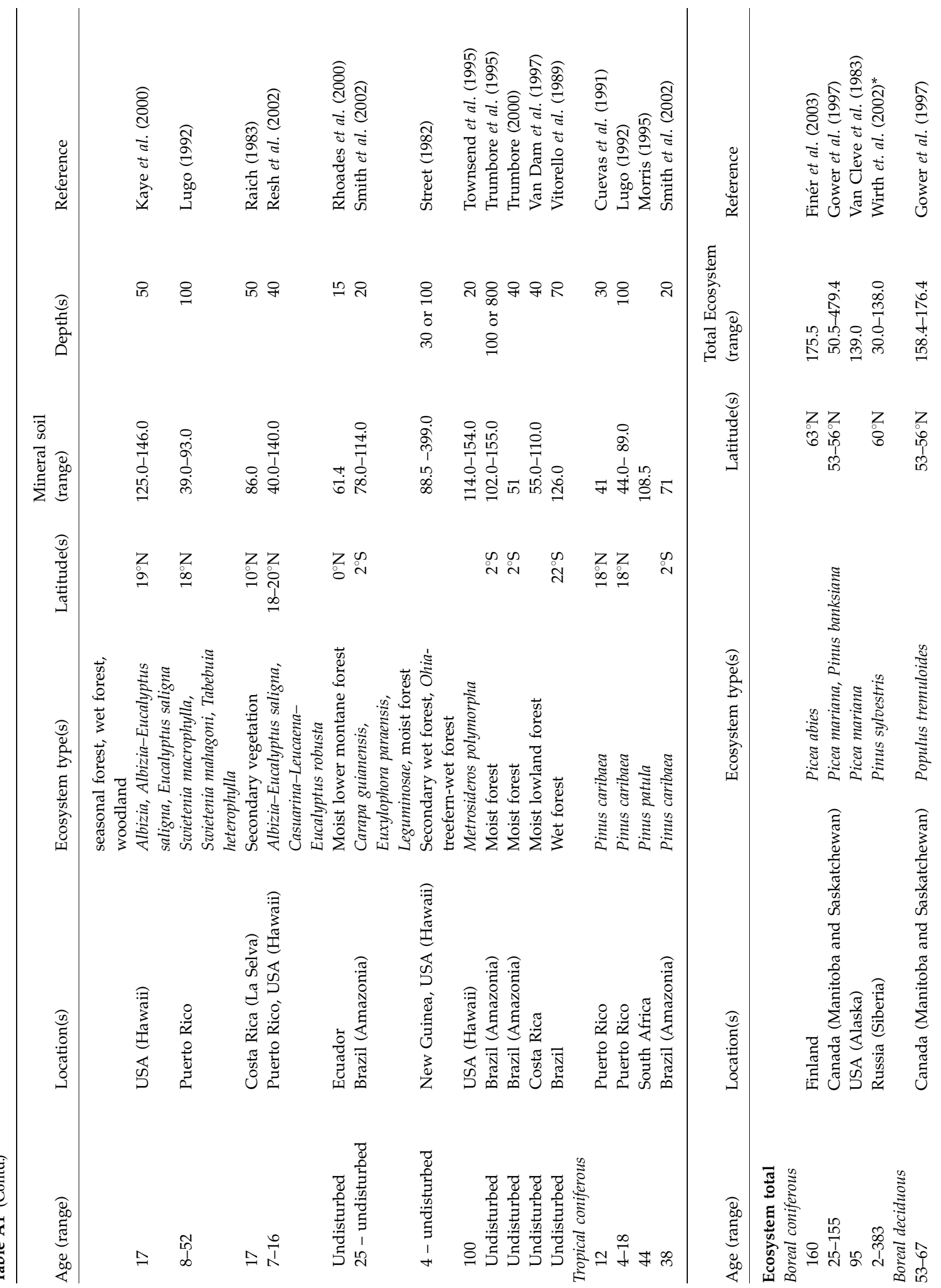


2074 K. S. PREGITZER \& E. S. EUSKIRCHEN

ڤัฒ

ลิ

के च्वे के

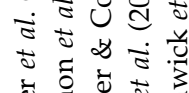

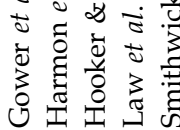

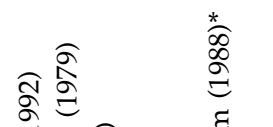

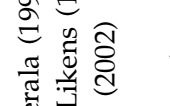

बू

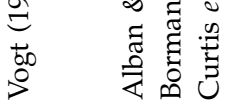

它

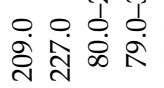

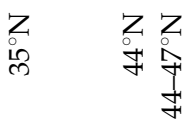

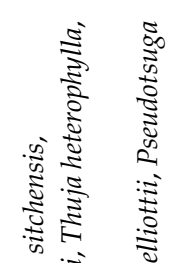

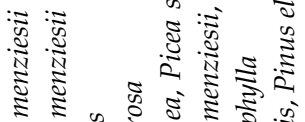

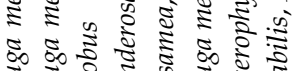

के की 0 क

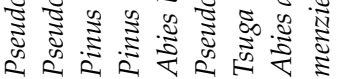

के

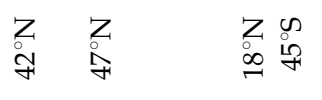

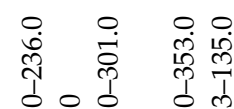

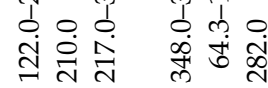

ำ

लि

길

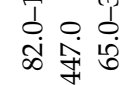

$x \sqrt{1}$

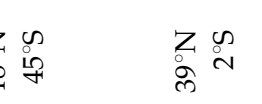

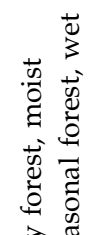

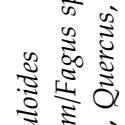

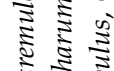

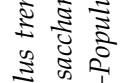

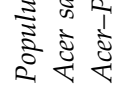

$\frac{\sqrt{3}}{\sqrt{3}}$

क्ष

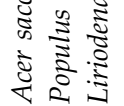

$\simeq \begin{aligned} & 0 \\ & 0\end{aligned}$

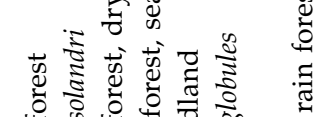

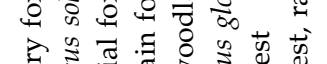

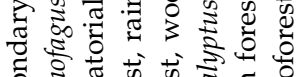

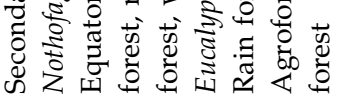

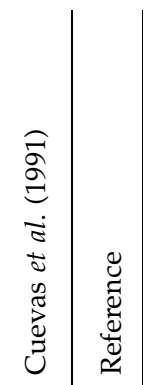

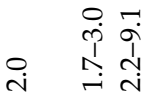

$\begin{array}{lll}z & z & z \\ 0 & 0 \\ 0 & 0 \\ 0 & 0 \\ 1 & 1 \\ 1 & 1\end{array}$

莹

:

帘

:

娄: :

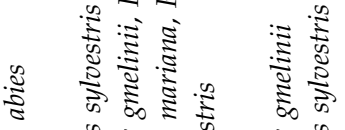

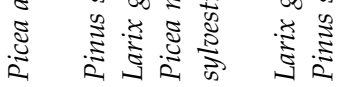

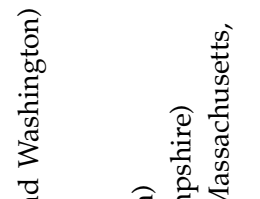

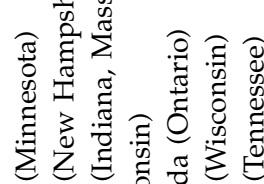

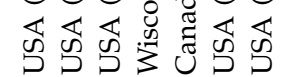

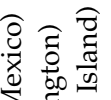

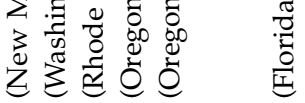

虫出出出出

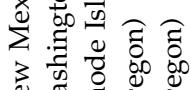

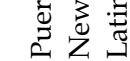
छัँ

$\frac{\sqrt{3}}{\frac{3}{5}}$

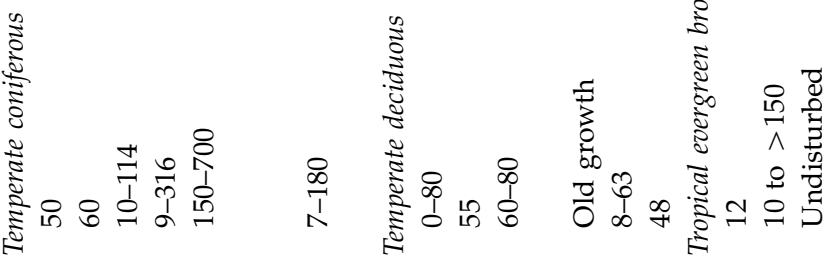
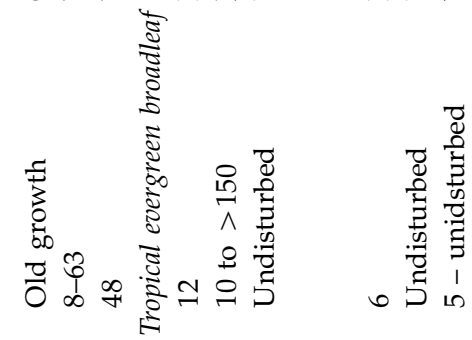
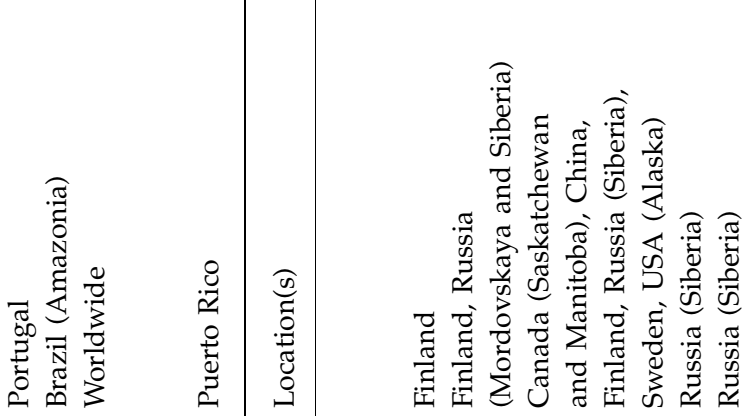

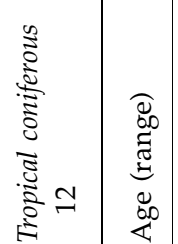

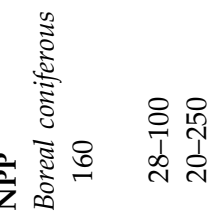

: 


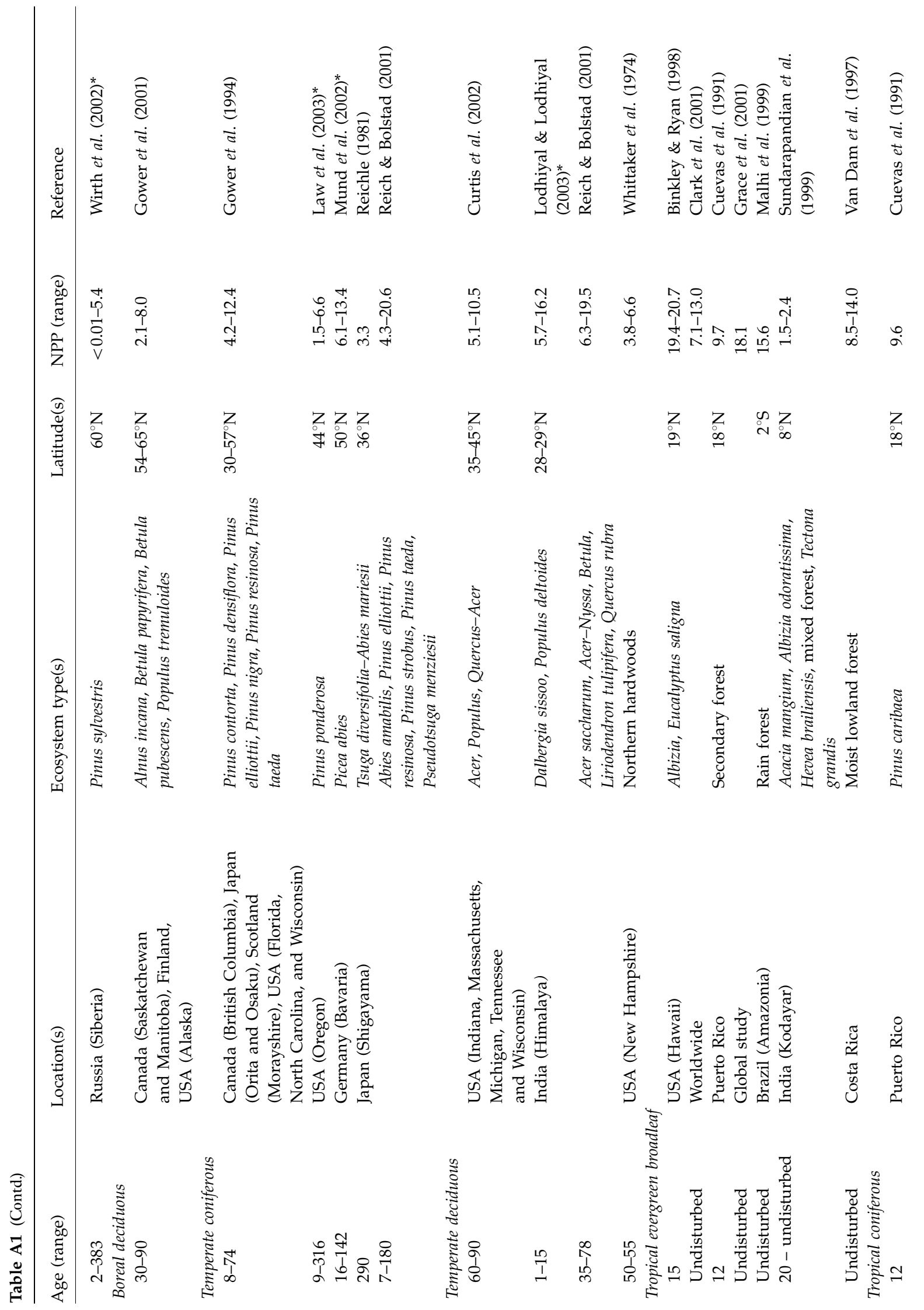




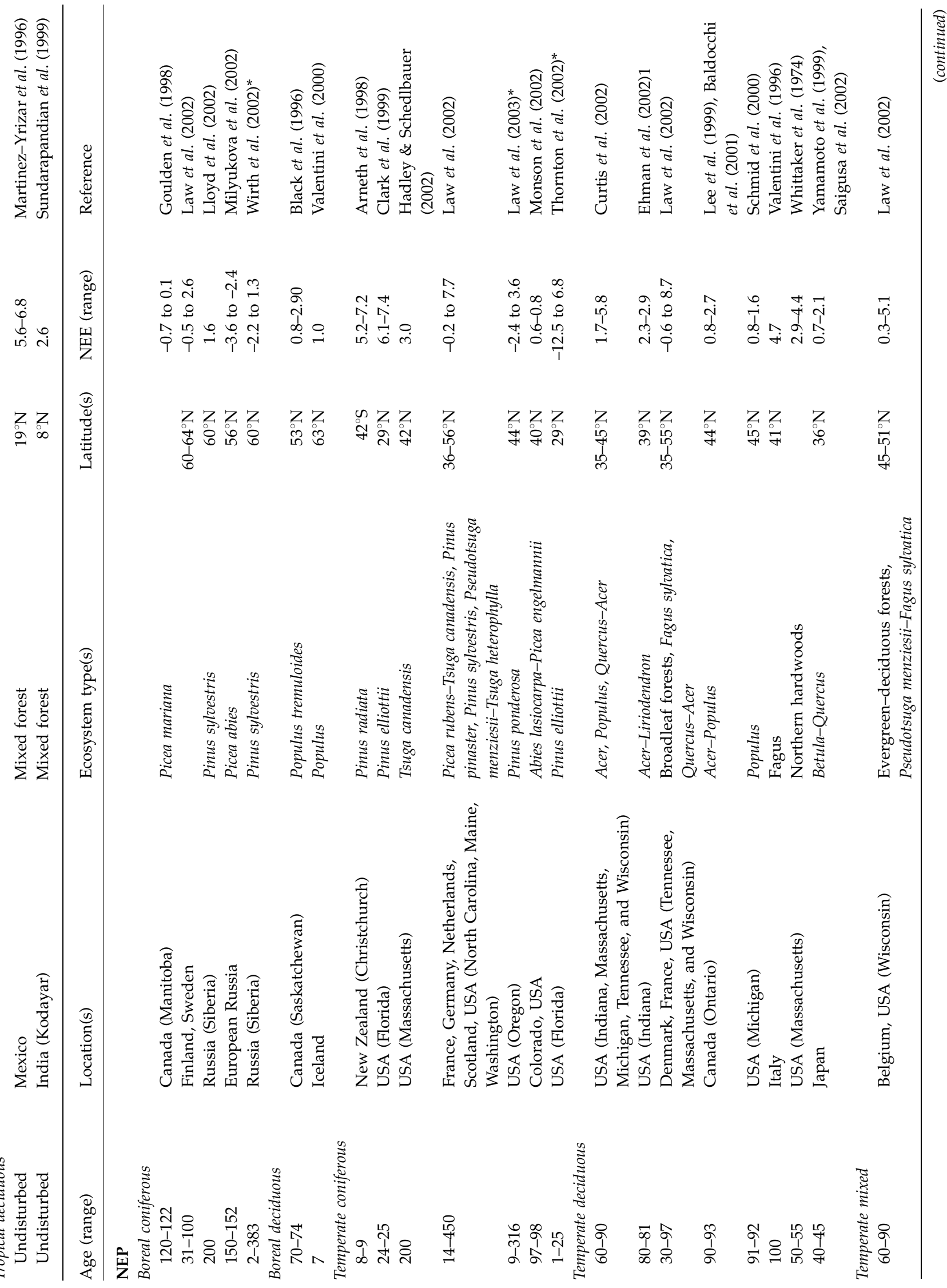


CARBON CYCLING AND STORAGE IN WORLD FORESTS 2077

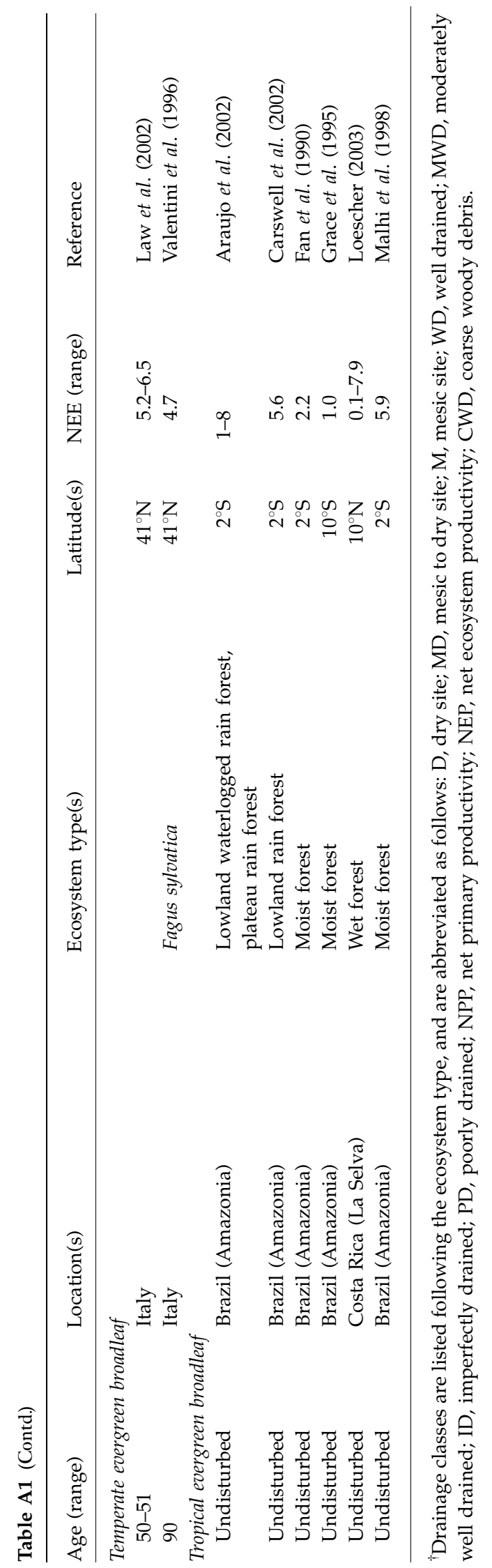

(C) 2004 Blackwell Publishing Ltd, Global Change Biology, 10, 2052-2077 